This item was submitted to Loughborough's Research Repository by the author.

Items in Figshare are protected by copyright, with all rights reserved, unless otherwise indicated.

\title{
Exchange rate hysteresis in the UK imports from the South Asian Countries
}

PLEASE CITE THE PUBLISHED VERSION

https://doi.org/10.1016/j.iref.2018.03.007

\section{PUBLISHER}

(c) Elsevier

VERSION

AM (Accepted Manuscript)

\section{PUBLISHER STATEMENT}

This work is made available according to the conditions of the Creative Commons Attribution-NonCommercialNoDerivatives 4.0 International (CC BY-NC-ND 4.0) licence. Full details of this licence are available at: https://creativecommons.org/licenses/by-nc-nd/4.0/

\section{LICENCE}

CC BY-NC-ND 4.0

\section{REPOSITORY RECORD}

Aziz, Nusrate, and A.H. Ahmad. 2019. "Exchange Rate Hysteresis in the UK Imports from the South Asian Countries". figshare. https://hdl.handle.net/2134/32509. 


\title{
Exchange Rate Hysteresis in the UK Imports from the South Asian Countries ${ }^{1}$
}

\author{
M. Nusrate Aziz ${ }^{2}$
}

and

\author{
A. H. Ahmad ${ }^{3}$
}

\begin{abstract}
We investigate and find evidence for the hysteresis hypothesis in UK imports from South Asian countries, using a monthly sample of data that covers 1999 to 2012. This paper finds evidence of the asymmetric effect of exchange rate volatility that 'large' depreciations significantly reduce UK imports from Bangladesh; however, 'large' appreciations do not increase the imports significantly. We also find a partial support for the hysteresis hypothesis in UK imports from India, Pakistan, and Sri Lanka. We find that hysteresis can be both country- and commodity-dependent, which is largely consistent with previous empirical studies. Theoretical literature suggests that hysteresis occurs due to the presence of sunk costs, however, we find that hysteresis occurs even beyond the sunk costs.
\end{abstract}

Keywords: Hysteresis hypothesis, Sunk costs, Exchange rates, South Asia

JEL Classification: C22, F31, F32

\footnotetext{
${ }^{1}$ We are grateful to the editor and two anonymous reviewers for their very useful and constructive comments. We also acknowledge the useful comments received from Bruce Morley.

${ }^{2}$ Algoma University, Sault Ste. Marie, Ontario, Canada.

${ }^{3}$ School of Economics, Loughborough University, Leicestershire, LE11 3TU, United Kingdom. A.H.Ahmad@lboro.ac.uk.
} 


\section{Introduction}

In his seminal work, Baldwin (1986) introduced the idea of 'hysteresis' - 'history matters' - in international trade. The work was motivated by the puzzling behaviour of the US trade in the 1980s in which the real value of the US dollar appreciated almost 40 percent in 18 quarters starting from the third quarter of 1980. However, starting from February 1985, the US dollar depreciated between 75 and 100 percent in real terms by the second quarter of 1987 . Notwithstanding, the US continued to experience a persistent trade deficit in this period. Baldwin (1986) portends that although the exchange rate appreciation pass-through into the real import price was approximately one-to-one, subsequent exchange rate depreciation did not affect the import prices a significant amount. Pricing-to-market, PTM, behaviour by foreign exporters was cited as one possible explanation. However, as pointed out by Baldwin (1988), the PTM is an implication, not an explanation for the hysteresis observed in the US trade. Fedoseeva and Werner (2016) have also found that PTM behaviour was responsible for German beer exports, however, they argue that the existence of sunk costs ${ }^{4}$ was the main explanation for the PTM behaviour.

A temporary real exchange rate shock should only have a temporary effect on trade prices and trade volumes; the size of the effect depends on the size of the exchange rate shock. However, if the market entry cost is sunk, a temporary exchange rate shock may have a persistent effect on trade which is referred to as 'hysteresis' in international trade (see, theoretical literature of Baldwin 1986, Baldwin 1988b, Baldwin and Krugman 1989, Dixit 1989a, Dixit 1989b, Baldwin and Lyons 1994, Roberts and Tybout 1997, and Impullitti, Irarrazabal and Opromolla 2013; and also empirical work of Bean 1987, Baldwin 1988a, Parsley and Wei 1993, Anderton 1999, Giovannetti and Samiei 1995, Martinez-Zarzoso 2001 and Campa 2004). The empirical

\footnotetext{
${ }^{4}$ Sunk costs refer to costs which cannot be recovered by an enterprise.
} 
literature reports mixed results on the existence of hysteresis in trade. For example, Bean (1987), Baldwin (1988), Anderton (1999), Campa (2004) and Kannebley (2008), Belke et al (2013), Belke and Kronen (2016), and Fedoseeva and Werner (2016) find support for the hysteresis hypothesis. However, Giovannetti and Samiei (1995) and Parsley and Wei (1993) find only a partial support for this hypothesis. In fact, Parsley and Wei (1993) cast doubt on the validity of hysteresis in US imports. Similarly, Verheyen (2013) and Aray (2015) report non-significance of hysteresis. Martinez-Zarzoso (2001) on the other hand, indicates that hysteresis effect can be both a commodity and a country-specific issue.

This study makes the following contributions to the literature. First, the existing empirical literature investigates the hysteresis hypothesis without identifying the effect of appreciation and depreciation separately (for example, Baldwin 1988, Anderton 1999, and Bean 1987). In contrast, this study tests the hysteresis hypothesis by separating the effect of exchange rate appreciation from depreciation.

We test the hysteresis hypothesis in UK imports from four South Asian countries. These Asian countries export very similar types of products to the UK and they are located within the same geographic region. These countries are very similar in terms of labour abundance, scarcity of capital, labour intensity in the production process, and factor productivity. The UK is one of the main export destinations for these countries. The above similarities, therefore, give us an opportunity to minimize heterogeneity in our sample and reach a robust conclusion. Additional motivation for covering these countries is the fact that the UK has historical ties with these South Asian countries which have translated into economic and trade relationships. Trade flows between the UK and the sample countries has been established for centuries and has not 
diminished in importance as it endures, even in the face of the recent financial crisis. ${ }^{5}$ These are the reasons why we estimate the hysteresis hypothesis in UK imports from these South Asian Countries.

Second, South Asian countries have been implementing export-led growth policies since around the mid-1980s, which are reflected by frequent movements in their exchange rates and shifts in the exchange rate regime ${ }^{6}$. However, no studies until now have examined the hysteresis hypothesis in the trade flows of these countries. We, therefore, attempt to fill this gap in the literature.

Third, Dixit (1989) postulates that firms' entry and exit decisions depend on the magnitude of exchange rate movements. Dixit (1989) parameterized a threshold level for 'sunk entry costs'. Building on this idea, we construct and use exchange rate threshold variables to estimate sunk costs. By applying constructed threshold variables, this paper investigates the effect of large exchange rate movements on bilateral trade. We also examine the validity of the theoretical view that sunk costs are the reason for hysteresis. In addition, we allow for flexibility in the threshold levels which captures both firm-specific, and time variant 'sunk costs' as suggested by Dixit (1989a and 1989b). Unlike the existing literature, this study employs a double-dummy approach to separately measure the effect of large appreciations and large depreciations on UK imports. Two different variables, representing large appreciations and depreciations, allow us to distinguish between the effect of each. A large depreciation at home would essentially reduce imports due to an increase in the price of imported goods. On the contrary, a large appreciation at home would raise imports because of a fall in prices of import goods. If the effect of large

\footnotetext{
${ }^{5}$ Figures 5 and 6 depict the UK imports and Exports from and to the sample countries, which shows a persistent trend for the sample period covered. It is worth mentioning that the former (imports) is more important for this study. However, the latter is reported to illustrate importance of bilateral trade flows between the UK and the countries.

${ }^{6}$ See Table 1 for details on de jure exchange rate regimes Bangladesh, India, Pakistan and Sri Lanka.
} 
depreciations and large appreciations are found empirically different (in size or significance), this would indicate that there is an evidence of exchange rate hysteresis in trade.

Fourth, existing literature examines the hysteresis hypothesis for developed countries. These comprise of Parsley and Wei (1993) and Baldwin (1988) for the US, Anderton (1999) for the UK, Giovannetti and Samiei (1995) for the US, Germany and Japan, Martinez-Zarzoso (2001), and Campa (2004) for Spain. Others are Belke and Kronen (2016), Fedoseeva and Werner (2016), and Belke et al (2013) for German and Greek exports to non-Euro countries. Very few studies have estimated the hysteresis hypothesis for developing countries, apart from Kannebley (2008) who considered the hysteresis hypothesis in Brazilian exports. However, developing countries (particularly South Asian countries) are more concerned about their exchange rate policy and international trade than developed countries. Many developing countries are undertaking export-led growth policies as a major strategy in their development process. Therefore, testing for the hysteresis hypothesis is useful for developing countries, from a policy-making perspective.

We find support for the hysteresis hypothesis and further show that hysteresis could be country and commodity-specific as being reported in the previous literature (see, Martinez-Zarzoso, 2001). In addition, we point out that 'sunk costs', which is traditionally considered as the reason for hysteresis in international trade, are not entirely responsible for hysteresis in trade. We find evidence of hysteresis in UK imports even after minimizing the sunk costs effect.

This is worth noting that the definition of the exchange rate used in our study is the units of domestic currency per unit of foreign currency. An increase in the exchange rate, therefore, represents depreciation while a decrease indicates an appreciation. 
The rest of the paper is organized as follows. Section 2 gives a theoretical discussion on hysteresis hypothesis. Section 3 discusses the exchange rate threshold, trade flows and the construction method of hysteresis dummies. Section 4 explains the data, methodology and estimation techniques. Section 5 discusses the estimated results, while Section 6 concludes.

\section{Hysteresis and Sunk Costs}

Currency depreciation generally reduces imports of a country as a result of an increase in import prices. If there is a large depreciation in the domestic currency, imports become more expensive, leading to a large fall in import demand. Consequently, some of the existing exporting firms (supply side) would find their business unprofitable, forcing them to exit the market. For example, suppose Bangladesh and China export the same product, $X$, to the UK. Assume that the pound sterling has largely depreciated against the foreign currency. Hence, import demand of product $X$ has fallen due to higher import prices. Let us assume that Chinese firms stay in the market with the pricing-to-market (PTM) strategy. However, Bangladeshi firms exit from the UK market because they are unable to follow the PTM strategy. If they follow the PTM strategy they end up with a loss due to their high production costs. In this case, Chinese firms capture a greater market share in the UK.

When the reverse situation occurs, i.e., domestic exchange rate appreciates and the exchange rate returns to its previous level, foreign incumbents (e.g., Chinese firms) remain active with a larger market share, but no new potential foreign entrant could enter the market. In our example, Chinese firms capture a greater market share and remain active with a larger market share. Consequently, Bangladeshi firms cannot re-enter into the UK market. Hence, a temporary shock in the exchange rate leads to an irreversible effect on international trade. 
Conceptually, this asymmetric behaviour may also occur in the opposite direction - a large appreciation increases imports, but when the reverse situation arises (a large depreciation occurs), there will be no significant fall in imports. One of the important reasons for hysteresis in trade is, therefore, the PTM behaviour by the exporting firms. ${ }^{7}$ However, this is possible if the PTM strategy is inexpensive to exporters.

Existing theoretical studies suggest that 'sunk costs' are the main reason for the occurrence of hysteresis. Empirically, 'sunk costs' can be captured by an exchange rate threshold. There exists a 'no-entry-no-exit' band in our exchange rate threshold which can capture the effect of sunk costs. When the exchange rate movements remain within the 'no-entry-no-exit' band, no new firms enter the market while the incumbents do not exit the market. To capture sunk costs and test whether 'hysteresis' occurs due to the existence of sunk costs, exchange rate movements must be 'larger' in magnitude. The fact is that with 'smaller' movements in the exchange rate, any entry or exit of firms to an export market are not cost effective. This socalled 'larger' term can be defined in terms of both size and duration. This 'larger' term in our study refers to ‘a larger movement in magnitude' and 'a longer movement in terms of time' as suggested by Parsley and Wei (1993).

Figure 1 illustrates the importance of sunk costs in international trade. The figure depicts the relationship between imports and the exchange rate in the presence of hysteresis. As can be observed from the figure, it shows that any exchange rate movement between $S_{0}$ and $S_{1}$ (which is considered as 'not a larger movement') cannot influence the decision, whether a foreign firm should enter the export market, or any existing firm should exit the market, due to sunk costs. Foreign firms enter the market only if appreciation in the importer's currency persists for a longer period and/or if the appreciation is larger in magnitude. This 'longer time' and 'larger

\footnotetext{
${ }^{7}$ For the full discussion on hysteresis hypothesis, refer to Baldwin (1988) and Anderton (1999).
} 
magnitude’ of exchange rate movements are vital for exporting firms to make their entry and exit decisions. If an exchange rate change is smaller in magnitude or shorter in duration, then it leads to a movement along the existing import demand curve (but does not shift the curve). On the contrary, any exchange rate movement from $S_{0}$ to $S_{2}$, which is a large appreciation in the importer's currency, entices new firms to enter the market. In this situation, foreign goods become cheaper to domestic consumers (importers). This causes a shift of the import demand curve from $M_{0}$ to $M_{1}$.

Figure 1 (around here)

Similarly, any exchange rate movement from $X_{1}$ to $S_{2}$ (which is not a large depreciation) cannot shift the import demand curve from $M_{1}$ to $M_{0}$. In this situation, existing firms continue their supply along $M_{1}$ because they have already incurred sunk costs. In this stage, exit from the market is expensive for them. Existing firms exit the export market only if exchange rate depreciation in the importer's currency is very large (something like a movement from $X_{1}$ to $S_{1}$ in Figure 1). In this situation, staying in the market is very costly for the exporter.

Now, let us assume that an exchange rate band exists for foreign firms which would determine their entry or exit decision. Suppose that the upper exchange rate threshold of the band is $s_{t}^{u}$ and the lower exchange rate threshold is $s_{t}^{l}$. If the current exchange rate is $e_{t}$, foreign firms' entry and exit decision can be explained as follows:

\begin{tabular}{lcc}
\hline & $\begin{array}{c}\text { Exchange Rate } \\
\text { Movements }\end{array}$ & Firms' decision \\
\hline Situation I & $e_{t}>s_{t}^{u}$ & Exit \\
Situation II & $s_{t}^{u}>e_{t}>s_{t}^{l}$ & No-entry-no-exit \\
Situation III & $e_{t}<s_{t}^{l}$ & Entry \\
\hline
\end{tabular}


Thus, if the current exchange rate $\left(e_{t}\right)$ moves between the lower band $s_{t}^{l}$ and upper band $s_{t}^{u}$, no new firms enter, and no existing firms exit their export market. Hence, following a depreciation or an appreciation in the importer's currency, there would be a decrease or an increase in imports, respectively, only when the exchange rate exceeds the upper band or the lower band of the threshold. Now assume that hysteresis occurs due to sunk costs. Only sufficiently large exchange rate movements (exceeding sunk costs equivalent) can influence a foreign firm to take an entry or exit decision because only the effect of sufficiently large exchange rate movements can outweigh the sunk costs.

Figure 2 illustrates how hysteresis occurs beyond sunk costs. Any exchange rate movement from $S_{0}$ to $E_{0}$ (not a sufficiently large appreciation) cannot shift the import schedule from $M_{0}$ to $M_{1}$ because of the presence of sunk costs. However, a large appreciation such as an exchange rate movement from $S_{0}$ to $S_{1}$ would lead to a shift from $M_{0}$ to $M_{1}$.

Assume that there is a large depreciation from $S_{1}$ to $S_{0}$ in Figure 2. As a result, the import demand curve has shifted back from $M_{1}$ to $M_{0}$. We can conclude, in this situation, that there is no hysteresis in trade. However, now assume that an opposite and equally large appreciation occurred in the importer's exchange rate. This does not necessarily shift the import demand curve back from $M_{0}$ to $M_{1}$. There are two possibilities: first, the import demand curve $\left(M_{0}\right)$ may not shift at all, but there may be some movements which occur along the existing import demand curve. Second, the import demand curve may shift to a new level, such as $\boldsymbol{M}_{3}$ (which is less than a shifting to $M_{1}$ ). Both cases will lead to hysteresis. 
Now suppose that our middle-band (no-entry-no-exit) is extended so that it can capture sunk $\operatorname{costs}^{8}$. This follows that any hysteresis found in trade is not due to sunk costs.

\section{Construction of the Exchange Rate Threshold}

Following Parsley and Wei (1993), we compute exchange rate thresholds for explaining hysteresis. The effect of depreciation following a cumulative depreciation could be different from the effects of depreciation following a cumulative appreciation. Accordingly, $s_{t}$ is defined as a cumulative change in exchange rate, which is measured as follows:

$$
S_{t}=\sum_{i=0}^{\tau} \Delta e_{t-i}=e_{t}-e_{t-\tau-1}
$$

where $\Delta e_{t}$ is the first difference of exchange rate, and $\tau$ is the number of periods, then the

hysteresis dummy ${ }^{9}, d_{t}$ can be characterized as follows, as in Parsley and Wei (1993):

$$
d_{t}=\left\{\begin{array}{cc}
1 & \text { if } \Delta \mathrm{e}_{\mathrm{t}}>0 \text { and } \mathrm{s}_{\mathrm{t}}>0 \\
-1 & \text { if } \Delta \mathrm{e}_{\mathrm{t}}<0 \text { and } \mathrm{s}_{\mathrm{t}}<0 \\
0 & \text { otherwise }
\end{array}\right.
$$

\footnotetext{
${ }^{8}$ We have allowed the variation in the middle band by using the exchange rate movements of 13 months (more than 1 year), 25 months (more than 2 years) and 37 months (more than 3 years), assuming the bands with longer movements can capture sunk costs.

${ }^{9}$ It accounts for cumulative changes in exchange rates and used as a proxy for hysteresis because of an assumption that cumulative appreciation (depreciation) followed by a current appreciation (depreciation) denote, so called, "larger" change in the exchange rate that is sufficient enough to be outside the middle-band and consequently lead to entry (exit) into the markets. It is worth noting that in some cases (in the series) the cumulative change appears to be positive in one month, then is found to be negative in the next month. In that case, we cannot say that the exchange rate change has lasted sufficiently long to capture so called 'larger' movements. It is just to remind the readers that our 'larger' term includes both bigger magnitude and longer period. Bigger magnitude could be captured by cumulative change, but longer period should be captured by a stable movement in the exchange rate. If we impose a restriction that both cumulative and current change must be in the same direction, we find that many observations are not qualified for so called 'larger' movements. Thus, we can capture both larger and longer terms in our exchange rate threshold. For further detail, please see, page 609, Parsley and Wei (2003).
} 
where $d_{t}$ takes the value of 1 if both the first difference $\left(\Delta e_{t}\right)$ and cumulative changes $\left(s_{t}\right)$ in exchange rates are in the positive direction, -1 if both are in the negative direction, or 0 (zero) if they are in opposite directions. If the current change and cumulative changes are in opposite direction it indicates that the depreciation or the appreciation is not sufficiently 'large' to induce either entry or exit from the market. This is because the plus and the minus reduce the magnitude of the change, and exchange rate movement has not taken place over a sufficiently long period. Thus, this opposite outcome of cumulative and current changes results in the value of the hysteresis dummy to be equal to zero ('no-entry-no-exit' band).

Figure 3 represents the bilateral exchange rates of the pound sterling against the currencies of the countries in the sample. The figure shows that although the magnitude of the exchange rates varies, the pattern seems to be similar for all bilateral exchange rates. This suggests that there is homogeneity in exchange rate movements in the sample. The shaded area refers to the financial crisis period. It indicates that during the global financial crisis, the movements of the currencies are uniform, and the pound sterling depreciated against South Asian countries' currencies during the global financial crises.

It is worth mentioning that we are interested in the shifting of the import demand function due to large exchange rate movements which can be captured by an intercept dummy (see, Anderton 1999, and Baldwin 1988), i.e., we are not interested in the change in slope of the import demand curve. The above hysteresis dummy (equation (2)), thus, can show us whether the intercept of the import demand function is significantly different due to large exchange rate movements. However, the weakness of this single dummy is that it can only show us if the import demand function shifts significantly due to large exchange rate movements; it does not show us the impact of large appreciations and large depreciations, separately. In other words, it does not show us whether the import demand curve shifts due to an appreciation or 
depreciation. This requires us to construct both large appreciation and large depreciation dummies separately. We, therefore, construct the following dummies (i.e., a double-dummy approach).

Using equation (2) as a benchmark, we construct two separate dummy variables, one for large appreciation and another for large depreciation, as follows:

$$
d_{t}^{i}=\left\{\begin{array}{c}
1 \text { if } \Delta e_{\mathrm{t}}>0 \text { and } \mathrm{s}_{\mathrm{t}}>0 \\
1 \text { if } \Delta e_{\mathrm{t}}<0 \text { and } \mathrm{s}_{\mathrm{t}}<0 \\
0 \quad \text { otherwise }
\end{array}\right.
$$

where $i=\{A, D\}$; ' $\mathrm{D}$ ' stands for depreciation and 'A' for appreciation. The depreciation dummy $\left(d_{t}^{D}\right)$ takes the value of 1 (unity) if there is a large depreciation after a cumulative depreciation and 0 (zero) otherwise. It takes the value of 0 (zero) if cumulative change and current change are in opposite directions, as well as if there is an appreciation after a cumulative appreciation $^{6}$. This indicates that hysteresis dummy takes a value of zero when there is no persistent and large movement in the exchange rate. Similarly, the appreciation dummy $\left(d_{t}^{A}\right)$ equals 1 (unity) if there is a large appreciation after a cumulative appreciation, and 0 (zero) otherwise. The hysteresis dummies, therefore, carry three distinguishable features: large appreciations, large depreciations, and the middle band. Current changes are measured as monthly changes, and cumulative changes are captured by the changes in the exchange rate for 13 months (more than 1 year), 25 months (more than 2 years), and 37 months (more than 3 years). We allow for variation in cumulative changes to accommodate heterogeneity in firms and commodities, as suggested by Dixit (1989b). By allowing these variations we can also capture different speeds of exchange rate pass-through into the import prices. That is, in this study, both slow and fast exchange rate pass-through are counted for. The cumulative changes for longer periods such as 25 months and 37 months can account for sunk costs, too. 
The hysteresis hypothesis predicts that the coefficient of the hysteresis would be negative and significant in an import equation. This is because a large appreciation in an importer's exchange rate leads to an entry of new firms into the market which shifts the import schedule outward. Similarly, a large depreciation in an importer's exchange rate leads to an exit of some existing exporting firms (who face loss) from the market and, therefore, the import schedule shifts inward. Thus, if hysteresis is significant, one would expect the sign of the coefficient of the hysteresis dummy to be negative and significant.

More specifically, a large appreciation increases imports, which represents a negative relationship between the exchange rate and imports. On the other hand, a large depreciation will shift the import schedule inward which would again produce a negative coefficient. Hence, we expect a negative sign for both large appreciation and large depreciation dummies. The combined effect would also be negative. So, in a single dummy approach (equation (2)), if the sign of the dummy variable appears to be negative and significant, we would find evidence of hysteresis in trade. However, this result would not show us whether the effect of large appreciations is bigger than the effect of large depreciations, or vice versa. It also does not show us whether the negative sign emerged from large appreciations or large depreciations.

On the contrary, in a double dummy approach (equation (3)), if the coefficient of appreciation dummy is negative and significant, but the coefficient of depreciation dummy is not (or vice versa), we would conclude that there is hysteresis in trade. Moreover, we can clearly show whether appreciation or depreciation causes the shift in the import schedule; it clearly shows us whether new firms have started exporting during a large appreciation in the importer's exchange rate. It will also show us whether incumbents do not exit during a large depreciation in the importer's exchange rate, and vice versa. 


\section{Large Appreciations and Depreciations}

We can show the number and the size of large appreciations and depreciations during our sample period by constructing and plotting the break-points (see, Parsley and Wei, 1993). However, the construction and plot of "the break-points" are limited in showing whether we have a sufficient number of large appreciations and depreciations to estimate our model. Our intercept dummies are sufficient to show whether there is a shift in the import demand curve. As mentioned earlier, change in slope of an import demand curve is not our concern.

The break-points are computed based on the following procedure as in Parsley and Wei $(1993)^{10}:$

$$
\text { Break-point }=d_{t}^{i} \times \Delta e_{t} \times s_{t}
$$

where $i=\{A, D\}$, A stands for appreciation and $D$ for depreciation. The break points are plotted in Figures 4(a) - 4(d), which indicate large bilateral exchange rate movements in the pound sterling against South Asian currencies ${ }^{11}$. Figure 4(a) suggests that in the managed floating regime of Bangladesh's exchange rate, there seems to be more 'large' depreciations of the pound sterling than appreciations against Taka. However, between 2003 and the late- 2007, which coincides with the country's de jure ${ }^{12}$ free floating regime, there are more large appreciations in the pound sterling than large depreciations. The pound sterling depreciates

\footnotetext{
${ }^{10}$ See Parsley and Wei (1993) for the full details.

${ }^{11}$ It is worth noting that there exist several econometric threshold models which include Enders and Siklos (2001), Hansen and Seo (2002) and Tsay (1998). However, these models do not seem to be appropriate for this work. This is because, the first two are bi-variate models but this paper is interested in investigating multi-variate relationships. The Tsay (1998) model is based on vector autoregressive models, which does not account for cointegrating relationship that this paper is interested in.

12 Since the seminal work of Calvo and Reinhart (2002), exchange rate regimes declared by countries seem to differ with the actual regime and therefore, the former is known as de jure and the latter is de facto regimes.
} 
from the onset of the financial crisis onwards. It is also noticeable from the figure that the size of depreciations of sterling is larger during the financial crises period than in other periods.

Figures 4(b) and 4(c) depict the constructed threshold for Pakistan and India, respectively, in which there seem to be cyclical fluctuations in the exchange rates. During the sample period, the pound sterling first depreciates, then appreciates, and then later depreciates again against the Indian and Pakistani Rupee. The size of depreciations during the global financial crisis period is different in that they are exceptionally larger than in other periods. In the case of Sri Lanka, there are more episodes of sterling appreciations than depreciations as indicated by Figure 4(d). Hence, Figure 4(a) - 4(d) indicate that there is a sufficient number of large exchange rate movements above and below the threshold levels for Bangladesh, India, Pakistan and Sri Lanka. We, therefore, have enough observations to test the hysteresis hypothesis.

\section{Data, Empirical Methodology and Estimations}

This paper uses monthly aggregated and disaggregated UK bilateral import volumes and prices from the trade statistics database of the UK HM Revenue \& Customs, UK Government, for the periods between 1999:01 and 2012:04. Our product classifications are based on Standard International Trade Classification (SITC). Table 1 presents the SITC series that we have used in this study. There are ten industries covered in the study, which are enumerated in the table. The study also constructs the UK bilateral real exchange rates between the pound sterling and South Asian currencies by using the data from the International Financial Statistics (IFS) of the International Monetary Fund (IMF). The SITC-wise domestic PPIs of United Kingdom are

collected from the OECD database. We also use the producer price indices (PPIs) of Bangladesh, India, Pakistan and Sri Lanka, as well as UK industrial production index (a proxy for real income) sourced from IFS of the IMF. Figure 5 shows the logarithm of the volume of total import of UK from its South Asian trading partners covered in this study. Although there 
were large depreciations in the pound sterling at the time of the global financial crisis as shown in Figure 3, it seems that there was less magnitude in the fall in the UK imports from these countries. Figure 6 depicts the UK exports to the countries to indicate that the bilateral trade between the two countries is both ways. It is evident from the figure that the exports have not been persistently constant even during the financial crisis ${ }^{13}$. Table 2 reports the exchange rate regimes for the countries covered in the sample. We report both de-jure, as announced by the monetary authorities and de-facto regimes, as identified as the actual by $\mathrm{IMF}^{14}$. It is evident from the table that the de-facto and de-jure exchange rate regimes are different for the South Asian countries in our sample. For example, Bangladesh has announced that it has adopted a free-floating regime since May 2003, but the IMF de-facto indicated that the country has been on a conventional fixed peg arrangement. However, the de-facto regimes of India and Pakistan are not too different from the de-jure regimes.

\section{Empirical Model}

Based on Rose and Yellen (1989), Rose (1990), and Rose (1991) as well as other standard twocountry trade literature, demand for imports is assumed to be negatively related to relative prices $(R P)$ and positively related to domestic real income $(Y)$. The import demand function can be given as follows:

$$
\ln Q_{i, t}^{m}=\mu_{i}+\delta_{i} \ln R P_{i, t}^{m}+\lambda_{i} \ln Y_{t}+\psi_{i} d_{t}+u_{t}
$$

where $d_{t}$ is the hysteresis dummy; $u_{t}$ is the error, which takes the following form:

\footnotetext{
13 The exports are only meant to depict importance of bilateral trade between the UK and the sample countries only. This study is more concerned with the imports which are more susceptible to hysteresis.

${ }^{14}$ See footnote 9 .
} 


$$
u_{t}=\ln Q_{i, t}^{m}-\mu_{i}-\delta_{i} \ln R P_{i, t}^{m}-\lambda_{i} \ln Y_{t}-\psi_{i} d_{t}
$$

The model in equation (5) assumes that long-run relationship, i.e. cointegration exists between the variables. Using equation (5) and (6) and as in Hefferman (1997), the growth of $\ln Q_{i, t}^{m}$ can be written as:

$$
\begin{aligned}
\Delta \ln Q_{i, t}^{m} & =\alpha_{i}+\beta_{i} \ln Q_{i, t-k}^{m}+\gamma_{i} \Delta \ln R P_{i, t}^{m}+\phi_{i} \ln R P_{i, t-k}^{m}+\eta_{i} \Delta \ln Y_{i, t} \\
& +\kappa_{i} \ln Y_{i, t-k}+\theta_{i} d_{t}+\varepsilon_{i, t}
\end{aligned}
$$

where, $Q_{i, t}^{m}$ is the UK import volume; $R P_{i, t}^{m}$ is the relative prices of import for the UK, which is given by the industry-specific import prices divided by the industry-specific domestic price; $Y_{t}$ is the real income of the UK (proxied by industrial production index for aggregate import and industry-wise industrial production index for disaggregate import models); and $d_{t}$ is hysteresis dummy. If significant, $d_{t}$ will affect the constant of equation (7) and will shift the demand curve that is shown in Figure 1 and 2. The subscript $k$ is the lag length which is determined by the Schwarz Information Criterion (SIC). The model in equation (7) is extended to include the large depreciations $\left(d_{t}^{D}\right)$ and the large appreciation $\left(d_{t}^{A}\right)$ dummies discussed in the preceding sections. The model, therefore, takes the following form:

$$
\begin{aligned}
& \Delta \ln Q_{i, t}^{m}=\alpha_{i}+\beta_{i} \ln Q_{i, t-k}^{m}+\gamma_{i} \Delta \ln R P_{i, t}^{m}+\phi_{i} \ln R P_{i, t-k}^{m}+\eta_{i} \Delta \ln Y_{i, t}+\kappa_{i} \ln Y_{i, t-k} \\
& +\rho_{i} d_{t}^{D}+\pi_{i} d_{t}^{A}+\varepsilon_{i, t}
\end{aligned}
$$

As mentioned earlier, depreciation and appreciation typically have different effects on import; these two separate dummies would indicate whether the effect of large appreciations and large depreciations are systematically different or the same. If the size and significance of $\rho$ and $\pi$ 
are found to be different, this indicates that there is evidence of hysteresis in trade. Since, $d_{t}^{D}$ and $d_{t}^{A}$ are intercept dummies, they will affect the constant term $\left(\alpha_{i}\right)$ in equation (8).

We test the hysteresis hypothesis by employing an intercept dummy because we are interested in the shifting of the intercept of the import demand curve, not the change in the slope of the demand curve. If either $\rho$ or $\pi$ in equation (8) is negative and significant, and the other coefficient is insignificant, this confirms the presence of an asymmetry in the UK imports in response to large exchange rate movements. The coefficients of the first difference of the variables provide the short-run estimates, and the long-run coefficients are estimated from the lagged variables. We obtain them from estimated equations. In the long-run steady state,

$$
\Delta \ln Q_{i, t}^{m}=\Delta \ln R P_{i, t}^{m}=\Delta \ln Y_{i, t}=0
$$

thus, equation (7) ${ }^{15}$ can be written in terms of the long-run as:

$$
-\beta_{i} \ln Q_{i, t}^{m}=\alpha_{i}+\phi_{i} \ln R P_{i, t}^{m}+\kappa_{i} \ln Y_{i, t}+\theta_{i} d_{t}
$$

Hence, the long-run coefficients for the import demand function are as follows:

$$
\mu_{i}=-\alpha_{i} / \beta_{i}, \quad \delta_{i}=-\phi_{i} / \beta_{i}, \quad \lambda_{i}=-\kappa_{i} / \beta_{i} \text {, and } \psi_{i}=-\theta_{i} / \beta_{i}
$$

The study estimates the models specified in equations (7) and (8) and then derives equation (5) using the "delta methods" for both the aggregate and the disaggregate UK imports, discussed in Section 5 (as follows).

\footnotetext{
${ }^{15}$ We apply similar approach to calculate the long-run coefficients from model (8), as well.
} 


\section{Discussions of the Estimated Results}

Descriptive statistics of the UK imports from the South Asian countries in the sample are reported in Table 3. The industries covered vary from country to country depending on the availability of data. The highest number of industry level data that we find is for India; eight industries. Seven industries are covered in Sri Lanka, while six industries are covered in Pakistan. The country with the least number of industries is Bangladesh where data for four industries are available in the database. All series were subjected to a battery of unit root tests ${ }^{16}$ to identify their level of integration. The results indicate that the individual series are nonstationary $I(1)$ in levels, but stationary $I(0)$ in first difference. Consequently, Johansen cointegration tests were conducted and the results rejected the null of no cointegration between the series in favour of the alternative hypothesis of one cointegration. ${ }^{17}$ Subsequently, the study estimates the models specified in equations (7) and (8) ${ }^{18}$.

\subsection{The Short-run Dynamics and the Long-run Relationships}

In the double dummy case, hysteresis dummies can show whether large appreciations or large depreciations, or both, significantly shift the intercepts of the import demand function. If one of the dummies, but not both, is significant we conclude that there is an evidence of hysteresis in trade. However, if both dummies are significant (and the size of the coefficients are same) we conclude that there is no hysteresis in trade. However, in the single dummy approach, if the dummy is negative and significant, it indicates that there is hysteresis in trade (see, Parsley and Wei, 1993 for detail). The results in Tables 4, 5, 6 and 7 are obtained from the single dummy

\footnotetext{
${ }^{16}$ To this end, ADF, PP and KPSS were used and the results are consistent in that all the variables are I(1) on levels and $\mathrm{I}(0)$ on first difference.

${ }^{17}$ However, both the unit root test and the cointegration results are not reported in this paper in order not to unnecessarily make the paper too long. But they are available on request.

${ }^{18}$ For robustness checks, the ARDL test of cointegration was also conducted and the results rejected the null of no cointegration.
} 
approach for Bangladesh, India, Pakistan and Sri Lanka, respectively. These are the outcomes from the estimated model specified in equation (7).

The error correction model, ECM, and the long-run results for each of the countries are also reported in the tables. The results indicate that the hysteresis dummies are negative and significant for SITC 0 and SITC 7 for Bangladesh; SITC 5 and SITC 6 for Pakistan; and SITC 2 and SITC 5 for Sri Lanka and none for India. The results also show that the long-run UK GDP coefficient has a negative impact on imports from Bangladesh. This indicates that if the UK income level rises, UK citizens import less from Bangladesh. This perhaps suggests that an increase in the UK income leads the UK buyers to buy expensive products from the export competitors of Bangladesh.

Effects of appreciation or depreciation on the imports in terms of magnitude are very difficult to discern from the 'single-dummy approach'. It is also difficult to determine the type of asymmetry from the 'single-dummy approach'. Therefore, the double-dummy approach will shed more light on this and is consequently superior to the single-dummy approach. In other words, the advantage of the double-dummy over the single-dummy approach is that the former, having incorporated explicit effects of appreciation and depreciation, will indicate whether these changes in exchange rates have different effects on the imports.

The results obtained from the double-dummy approach are reported in Tables 8 to Table 11 . The results indicate that all the parameters, except the hysteresis coefficient, are of the expected signs and significant at the conventional level of significance for almost all SITC categories for all the countries. Table 8 contains the error correction term, ECM, results obtained from the model specified in equation (8) for Bangladesh. The depreciation dummy $\left(d_{t}^{D}\right)$ is found to be negative and significant for all sectors, except for SITC 6. The results also show that large depreciations in the pound sterling significantly affect the aggregate import and industrial 
imports of SITC 0, SITC 7 and SITC 8 from Bangladesh; however, large appreciations did not significantly affect the UK imports at the aggregate or disaggregate level. This indicates that large depreciations significantly reduce the UK imports from Bangladesh. However, when the situation is reversed, i.e., large appreciations occur, there was no increase in the UK imports from the country. Understandably, the result from the double-dummy approach is different from the results obtained from the single-dummy approach.

There emerge three implications from the estimated results using the double-dummy approach. First, depreciation has a negative and significant effect, but appreciation shows an insignificant effect on the UK imports. Hence, there is an asymmetric effect from large exchange rate appreciations and depreciations. Bangladeshi firms that exit the UK market during large depreciations of the pound sterling cannot re-enter the market during a favourable situation (large appreciation of the pound sterling). This implies that there is hysteresis in the UK imports from Bangladesh. Second, the asymmetry suggested by the presence of hysteresis is not like the asymmetric effect found for the US imports in the 1980s reported in Baldwin (1988) and Dixit (1989). Baldwin (1988) and Dixit (1989) found that those firms who enter the US market during a large appreciation, by applying the pricing-to-market strategy, do not exit the US market when there is a large depreciation in the US dollar. Third, the asymmetry found in UK imports from Bangladesh has not occurred due to sunk costs. This is because we alternatively applied dummies which are constructed using 13-month, 25-month and 37-month’s cumulative changes in the exchange rate. The latter two are assumed to be able to capture sunk costs. Hence, this hysteresis occurs beyond the effect of sunk costs. ${ }^{19}$

\footnotetext{
${ }^{19}$ During large depreciation in an importer's currency, small firms exit the market, however large firms stay in the market. During large appreciation in importers' currency, an incumbent captures a greater market share; it does not give a small firm a chance to enter the market again. This can be termed as a "third country effect" because the firms from China (compared with Bangladesh) may have a relatively advantage of low-cost production. Hence, firms from China are able to apply PTM strategy.
} 
The asymmetric effect in the UK imports from Bangladesh is different to that of the U.S. in the 1980s as reported by Baldwin (1988) and others, which could be due to the following reasons: First, Baldwin (1988) estimates hysteresis in the US imports from both developed and developing countries. This study estimates the hysteresis in the UK imports from only developing countries, and also from those countries with which it has historical ties and has maintained a strong trading relationship. It is worth mentioning that capacity utilization, pricing behaviour, production costs, and firms' size are different in developing countries from those prevailing in developed countries. Second, Baldwin (1988) tests the hysteresis hypothesis by using the import demand function at the aggregate level, but this paper estimates bilateral industry-specific import demand functions.

Table 9 contains the results for India. The appreciation dummy is negative and significant for aggregate import, and industrial imports of SITC 0 and SITC 8 of the UK from India. However, the depreciation dummy is not significant for those products. This appears to be similar to the asymmetric effect reported for the US imports in the 1980s in Balwin (1988) and opposite to what we find for Bangladesh. This may be because, unlike Bangladeshi exports, Indian exports are not affected by the pricing-to-market strategy of competing countries. Alternatively, Indian firms also stay in the UK market through PTM strategy during large depreciations in the pound sterling.

Similar to Bangladesh, the depreciation dummy is found to be negative and significant for UK industrial imports of SITC 5 from Pakistan, and SITC 2 and SITC 5 from Sri Lanka as shown in Tables 10 and Table 11, respectively. However, appreciation dummies are insignificant for the same categories (with an exception in SITC 6 from Sri Lanka). The appreciation dummy for industrial import of SITC 6 from Sri Lanka is negative and significant, but depreciation dummy is insignificant for this category. 
We also find that large depreciations significantly affect UK industrial imports of SITC 5 from Pakistan; however, large appreciations do not reverse it as reported in Table 6. Aggregate import and other industrial imports (except SITC 5) of UK from Pakistan have been unaffected by large appreciations and large depreciations. Therefore, hysteresis is not a significant issue for the UK imports from Pakistan for all industries, except for SITC 5.

It is clear from the above discussion that there is evidence of hysteresis in disaggregated imports (SITC 2, SITC 5 and SITC 6) to the UK from Sri Lanka. However, the type of hysteresis for SITC 2 and SITC 5 is different to that of SITC 6. Large depreciations significantly reduced UK industrial imports of SITC 2 and SITC 5 from Sri Lanka while large appreciations cannot increase those imports. On the contrary, large appreciations significantly increased UK industrial imports of SITC 6 from Sri Lanka, large depreciations cannot reduce it.

The foregoing suggests that there is hysteresis in almost all UK imports (except SITC 6) from Bangladesh. However, it is significant only in some industrial imports for the UK from India, Pakistan and Sri Lanka. This indicates that hysteresis is a country-specific phenomenon ${ }^{21}$. We also observe that there is evidence of hysteresis in a few industries in each country. For example, there is evidence of hysteresis in UK industrial import of SITC 5 from Pakistan and Sri Lanka. We also find an evidence of hysteresis in the industrial imports of SITC 0 and SITC 8 from Bangladesh and India. We, therefore, can conclude that hysteresis is an industry-specific as well as a country-specific phenomenon ${ }^{20}$. These are consistent with the findings of MartinezZarzoso (2001) who finds that the hysteresis hypothesis is both a country- and commodityspecific phenomenon for Spanish exports to other EU countries.

\footnotetext{
${ }^{20}$ This is because some industries (but not all) from some country (not all countries) appear to be characterised by the pricing-to-market (PTM) behaviour. Second, some goods are inelastic, and some are elastic in nature. Large exchange rate movements cannot influence the earlier types of commodities.
} 
We can conclude from the above discussion that first, hysteresis is both a country and commodity-specific issue; second, sunk costs are not entirely responsible for hysteresis in trade; third, there are two different types of hysteresis in UK imports: large depreciations have reduced UK imports from Bangladesh, Pakistan and Sri Lanka. However, large appreciations have not significantly increased UK imports from these countries. On the contrary, large appreciations have increased the UK imports from India. However, large depreciations have not significantly reduced the UK imports from India.

\subsection{Robustness Checks: Recursive Estimation}

In addition to standard diagnostic tests, which suggest that the models are adequate, we also computed recursive estimates. This is done for all the countries covered for both aggregate and industry-specific data. Figure 7 and Figure 8 depict the results for Bangladesh with two standard error bands around the estimated coefficients using the double-dummy and singledummy approaches, respectively ${ }^{21}$. The results of the recursive estimates in Figure 8 suggest that the coefficient of hysteresis for UK aggregate imports, and industrial imports of SITC 7 and SITC 8 are negative and significant over the sample period. However, it is not clear from the figure whether 'large' appreciations or 'large' depreciations, or both, have significant effects on the UK imports. On the contrary, results from the double-dummy approach (reported in Figure 7), as expected shed more light on that. It is clear from the figure that there is an asymmetric response of UK imports to large exchange rate movements. Large depreciations significantly reduce the UK imports. However, large appreciations do not significantly increase the UK imports from Bangladesh. Hence, confirming the results discussed above. We have not

\footnotetext{
${ }^{21}$ We have presented the recursive estimate results only for the UK imports from Bangladesh (as an example). Recursive estimate results of the UK import from other countries are found in accordance to the estimated results presented in Table 5, 6 and 7 for the single-dummy and Table 9, 10 and 11 for the double-dummy.
} 
reported the recursive estimates of UK imports from India, Pakistan and Sri Lanka (to save space) which are in accordance with the results reported in Table 9, 10 and 11.

\section{Conclusion}

Asian countries such as Bangladesh, India, Pakistan, and Sri Lanka have been pursuing exportled growth strategies for the last three decades. These countries have frequently devalued their currencies to gain a competitive advantage for their exports. They have also had a long and strong historical trade relationship with the UK.

This paper investigates exchange rate hysteresis in the UK imports from South Asian countries. Estimated results suggest that there is evidence of hysteresis in the UK imports from Bangladesh; however, there is partial support for hysteresis in the UK imports from India, Pakistan, and Sri Lanka. It also indicates that hysteresis is an industry-specific phenomenon. This is in accordance with the findings of Parsley and Wei (1993), Giovannetti and Samiei (1995), and Martinez-Zarzoso (2001).

The study also suggests that sunk costs are not the only reason for hysteresis; there is evidence of hysteresis even beyond the sunk costs effect. The ECM and the recursive estimates indicate that large depreciations significantly reduce the UK imports from Bangladesh. However, this is not reversed by large appreciations. Similar results are found for UK imports from Pakistan and Sri Lanka. On the contrary, we find that large appreciations increase the UK imports from India, however, large depreciations do not bring about the reverse. This is consistent with the findings suggested by Baldwin (1986) and other recent studies including Belke et al (2013), Belke and Kronen (2016), and Fedoseeva and Warner (2016). 


\section{Reference}

Anderton, Bob (1999), UK trade performance and the role of product quality, innovation and hysteresis: some preliminary results, Scottish Journal of Political Economy, Vol. 46, No. 5, pp. 570-595.

Aray, H. (2015), Hysteresis and Import Penetration with Decreasing Sunk Costs, International Economics and Economic Policy, 12:2, pp. 175-188.

Baldwin Richard (1986), Hysteresis in Trade, MIT mimeo prepared for 1986 NBER Summer Institute.

Baldwin, Richard (January 1988a), Some Empirical Evidence on Hysteresis in Aggregate US Import Prices, Working Paper No. 2483, NBER Working Paper Series

Baldwin, Richard (September 1988b), Hysteresis in Import Prices: The Beachhead Effect, The American Economic Review, Vol. 78, No. 4, pp. 773-785.

Baldwin, Richard and Krugman, Paul (1989), Persistent Trade Effects of Large Exchange Rate Shocks, The Quarterly Journal of Economics, Vol. 104, No. 4, pp. 635-654.

Baldwin, Richard E. and Lyons, Richard K. (1994), Exchange rate hysteresis: large versus small policy misalignments, European Economic Review, Vol. 38, No. 1, pp. 1-22.

Bean, Charles. 1987. "Sterling Misalignment and British Trade Performance." Centre for Labour Economics (LSE) Discussion Paper No. 288.

Belke, A. and Kronen, D. (2016) "Exchange rate bands of inaction and play-hysteresis in Greek exports to the Euro Area, the US and Turkey: sectoral evidence”, Empirica 43: 2, 349-390.

Calvo, G. A. and Carmen M. Reinhart (2002) "Fear of Floating”, The Quarterly Journal of Economics 117 (2): 379-408.

Campa, Jose Manuel (2004), Exchange rates and trade: How important is hysteresis in trade? European Economic Review, Vol. 48, pp. 527-548.

Dixit, Avinash (1989a), Entry and Exit Decisions under Uncertainty, Journal of Political Economy, Vol. 97, No. 3, pp. 620-638. 
Dixit, Avinash (1989b), Hysteresis, Import Penetration, and Exchange Rate Pass-Through, The Quarterly Journal of Economics, Vol. 104, No. 2, pp. 205-288.

Enders, W., \& Siklos, P. L. (2001). Cointegration and Threshold Adjustment. Journal of Business \& Economic Statistics, 19(2), 166-176.

Fedoseeva, S. and Werner, L. M. (2016) "How linear is pricing-to-market? Empirical assessment of hysteresis and asymmetry of PTM, Empirical Economics 50: Issue 3, 1065 1090.

Gagnon Joseph E. (1993), Exchange Rate Variability and the Level of International Trade, Journal of International Economics, Vol. 34, pp. 269-287.

Giovannetti, Giorgia and Samiei, Hossein (1995), Hysteresis in Exports, Research Department, International Monetary Fund.

Hansen, E. B. and Seo, B. (2002). Testing for two-regime threshold cointegration in vector error correction models. it J. Econometrics, 110, 293-318.

Heffernan, Shelagh A. (1997), Modelling British Interest Rate Adjustment: An Error Correction Approach, Economica, Vol. 64, pp. 211-231.

Impulliti, G, Irarrazabal A.A, and Opromolla L.D 2013. A Theory of Entry Into and Exit From Export Markets. Journal of International Economics 90(1):75-90.

Jobst, Clemens and Kwapil, Claudia (2008), The Interest Rate Pass-Through in Austria Effects of the Financial Crisis, Monetary Policy \& the Economy Q4/08, Quarterly Review of Economic Policy, Oesterreichische National Bank.

Jr., Sergio Kannebley (2008), Tests for the Hysteresis Hypothesis in Brazilian Industrialized Exports: A Threshold Co-integration Analysis, Economic Modelling, Vol. 25, pp. 171-190.

Ljungqvist, Lars (1994), Hysteresis in international trade: a general equilibrium analysis, Journal of International Money and Finance, Vol. 13, pp. 387-399.

Martinez-Zarzoso, I. (2001) "Does Hysteresis Occur In Trade? Some Evidence for Bilateral Export Flows at A Disaggregated Level”, The International Trade Journal, 15:1, 57-88. 
Orcutt, Guy H. (1950), Measurement of Price Elasticities in International Trade, Review of Economics and Statistics, vol. 32, No. 2, pp. 117-132.

Parsley, David C. and Wei, Shang-Jin (1993), Insignificant and Inconsequential Hysteresis: The Case of U.S. Bilateral Trade, Review of Economics and Statistics, Vol. 75, No. 4, pp. 606613.

Roberts, M., and J. Tybout (1997). An Empirical Model of Sunk Costs and the Decision to Export. American Economic Review 87 (4): 515-561.

Rose, Andrew K. (1990), Exchange rates and the Trade Balance- Some Evidence from Developing Countries, Economics Letters, Vol.34, pp. 271-275.

Rose, Andrew K. and Yellen, Janet L. (1989), Is There a J-curve?, Journal of Monetary Economics, Vol. 24 pp.53-68.

Rose, Andrew K. (1991), The role of exchange rates in a popular model of international tradeDoes the 'Marshall-Lerner' condition hold?, Journal of International Economics, Vol. 30 pp. 301-316.

Tsay, R. S. (1998) “Testing and Modeling Multivariate Threshold Models”, Journal of the American Statistical Association, Volume 93, Issue 443, 1998.

Qzdemir, Bilge Kagan (2009), Retail Bank Interest Rate Pass-Through: The Turkish Experience, International Research Journal of Finance and Economics, Issue 28, pp. 7-15.

Verheyen, F. (2013), Exchange Rate Non-linearities in EMU Exports to the US, Economic Modelling, 32, pp. 66-76. 
Figure 1

Import and exchange rate relation in presence of hysteresis

Exchange Rate

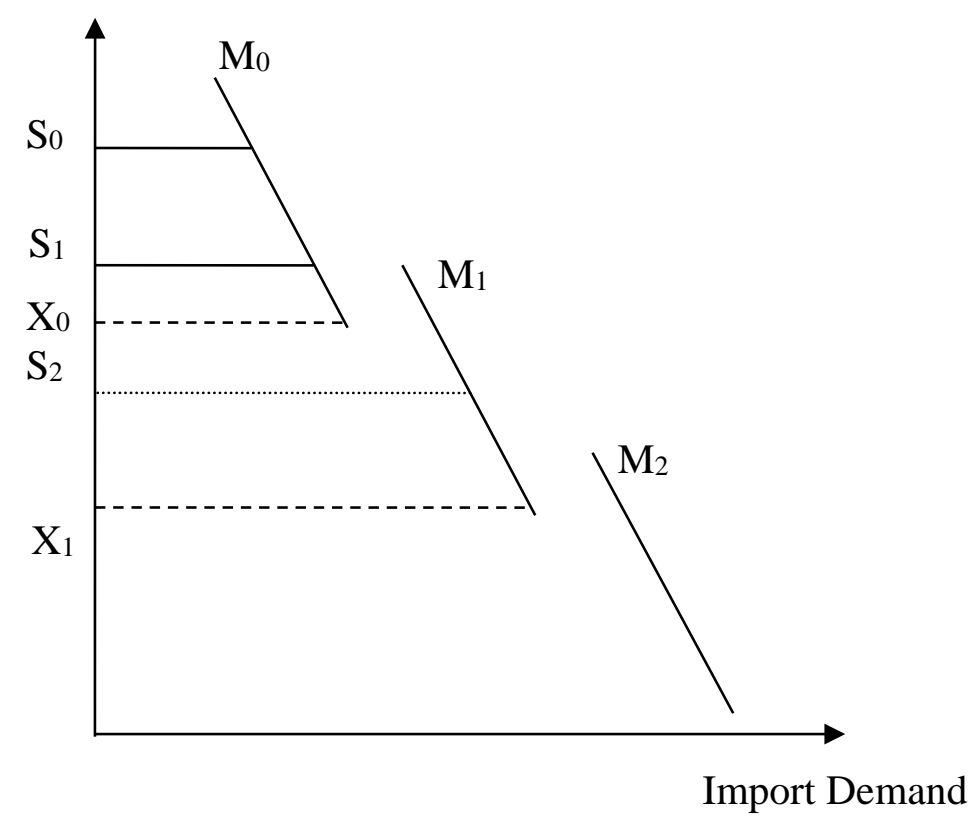

Source: Adopted from Parsley and Wei, 1995

Figure 2: Hysteresis beyond sunk costs

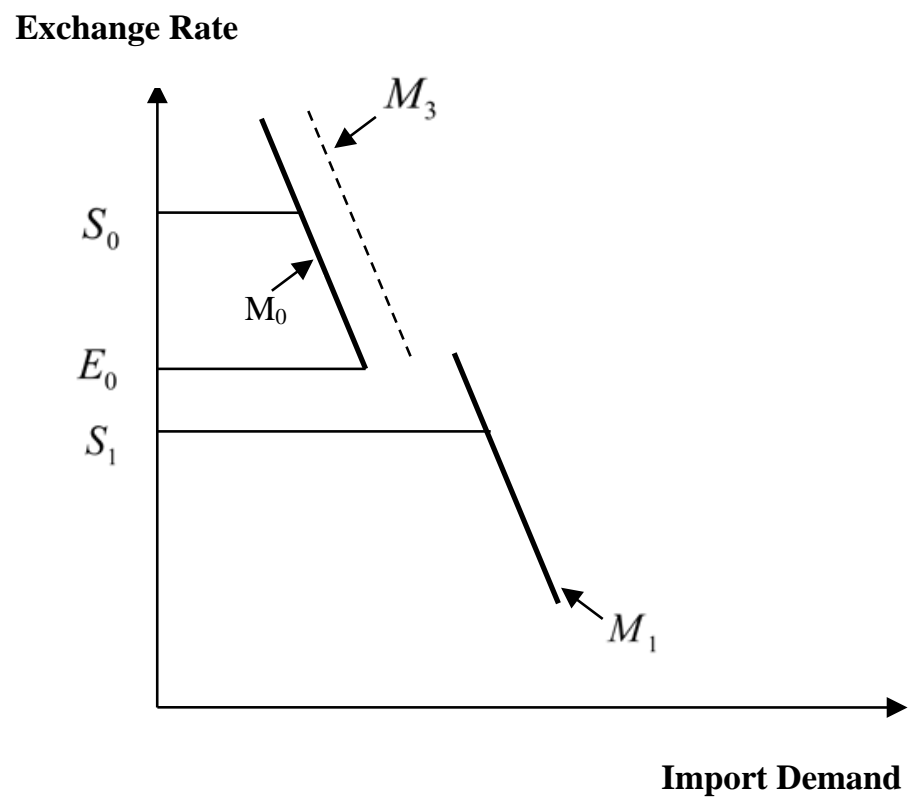


Figure 3: Real exchange rate of UK with South Asian countries

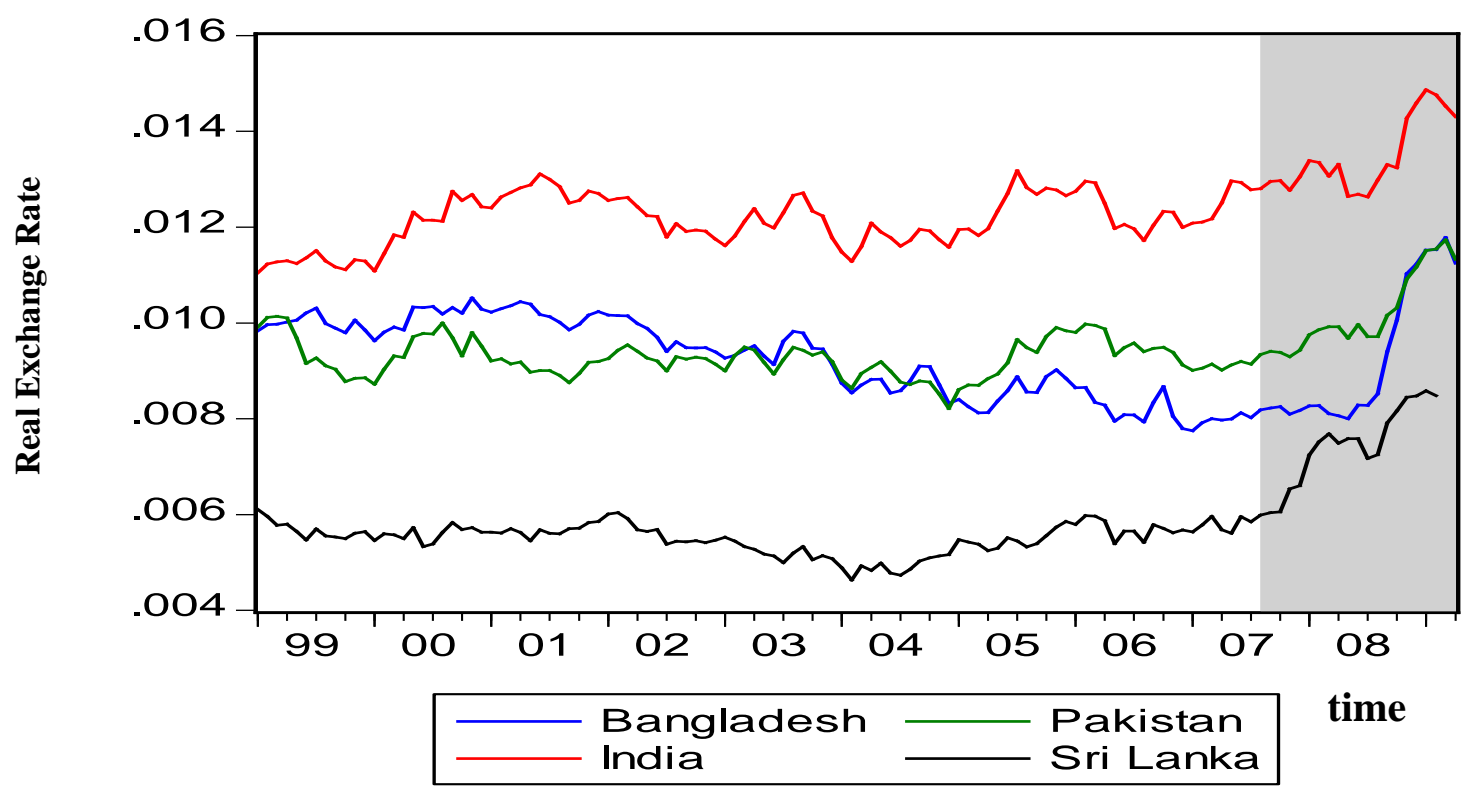


Figure 4(a): 'Large’ real appreciations and depreciations of Pound Sterling against Bangladeshi Taka
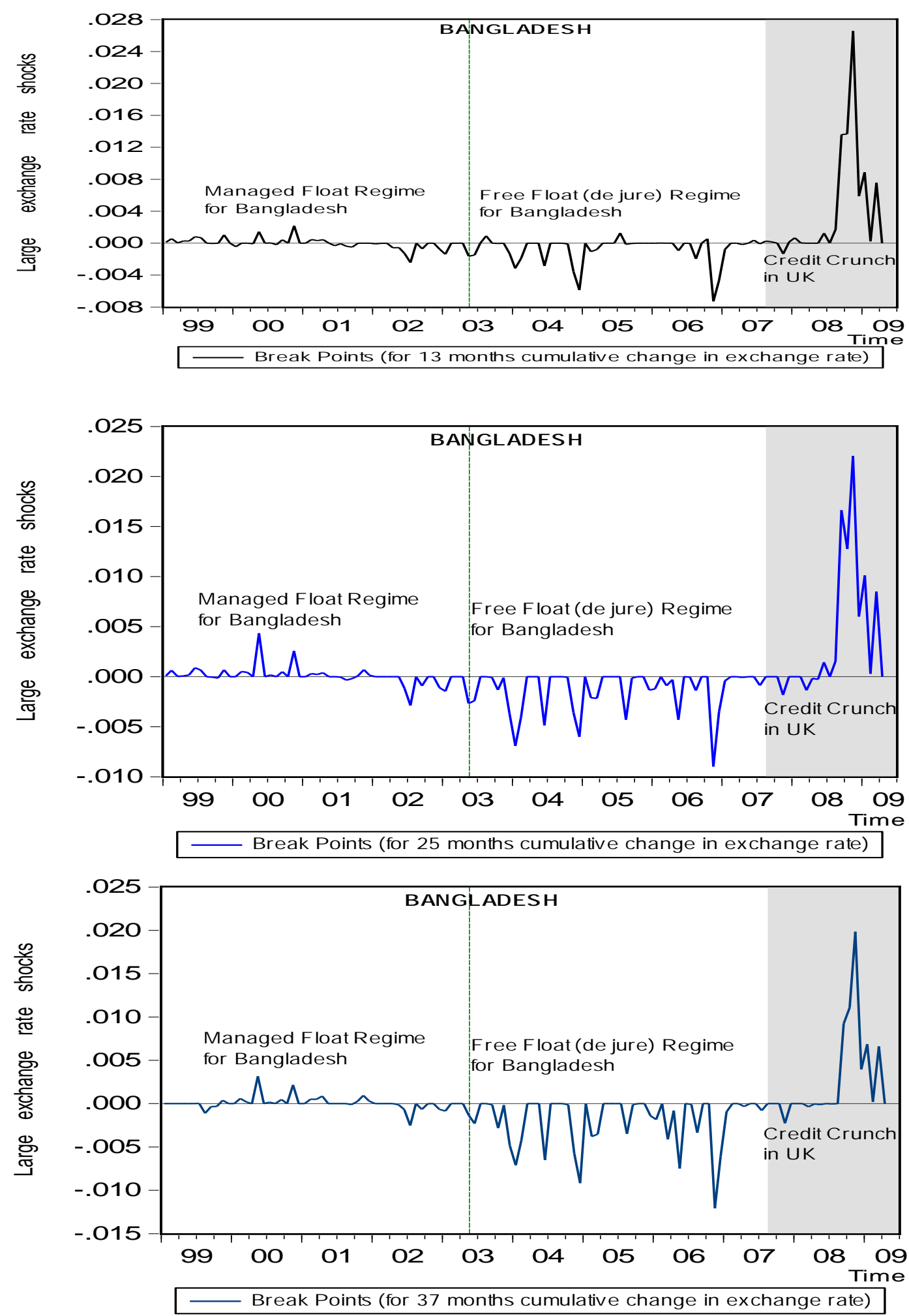
Figure 4(b): 'Large' real appreciations and depreciations of Pound Sterling against Indian Rupees
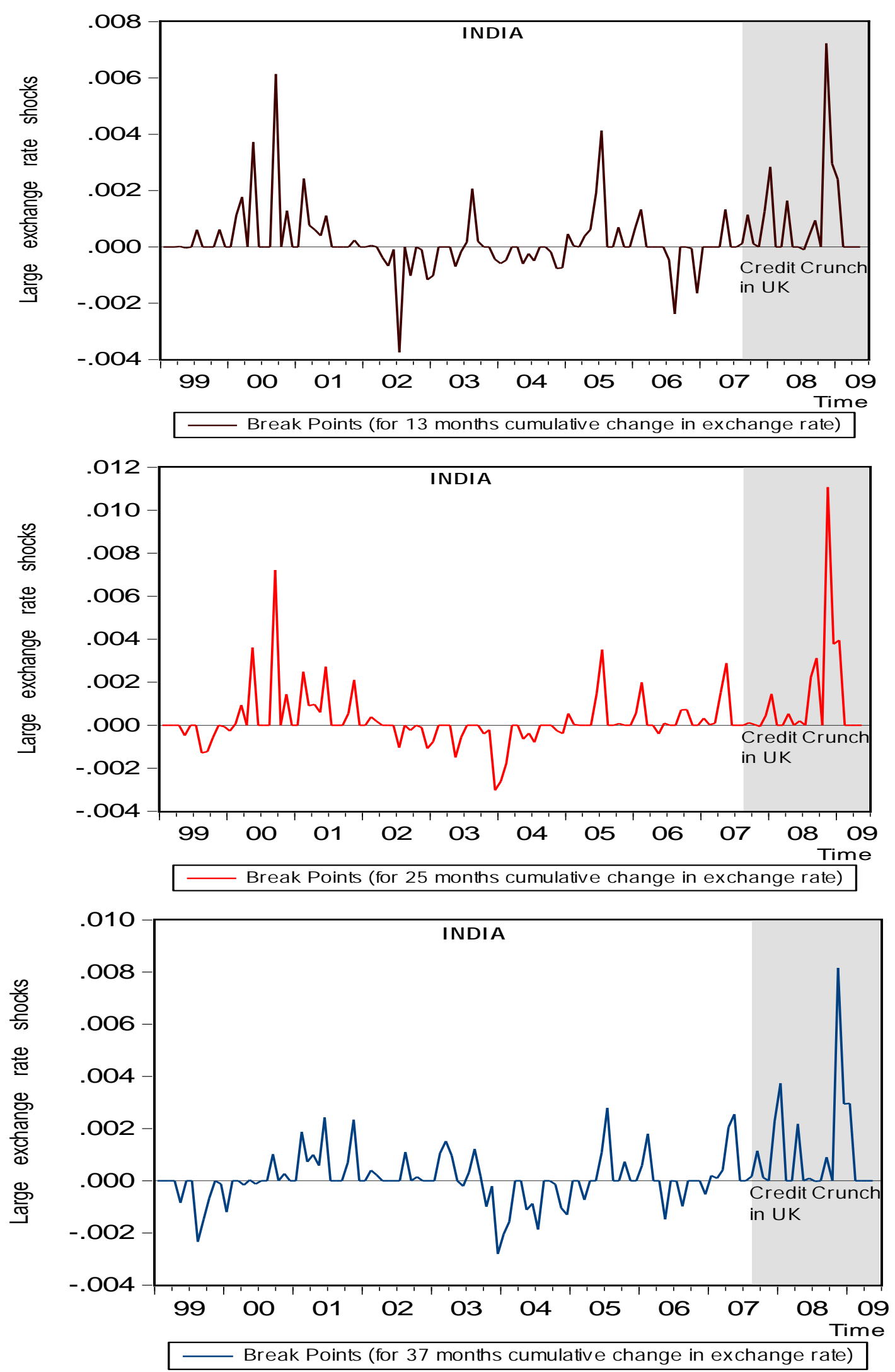
Figure 4(c): 'Large' real appreciations and depreciations of Pound Sterling against Pakistani Rupees
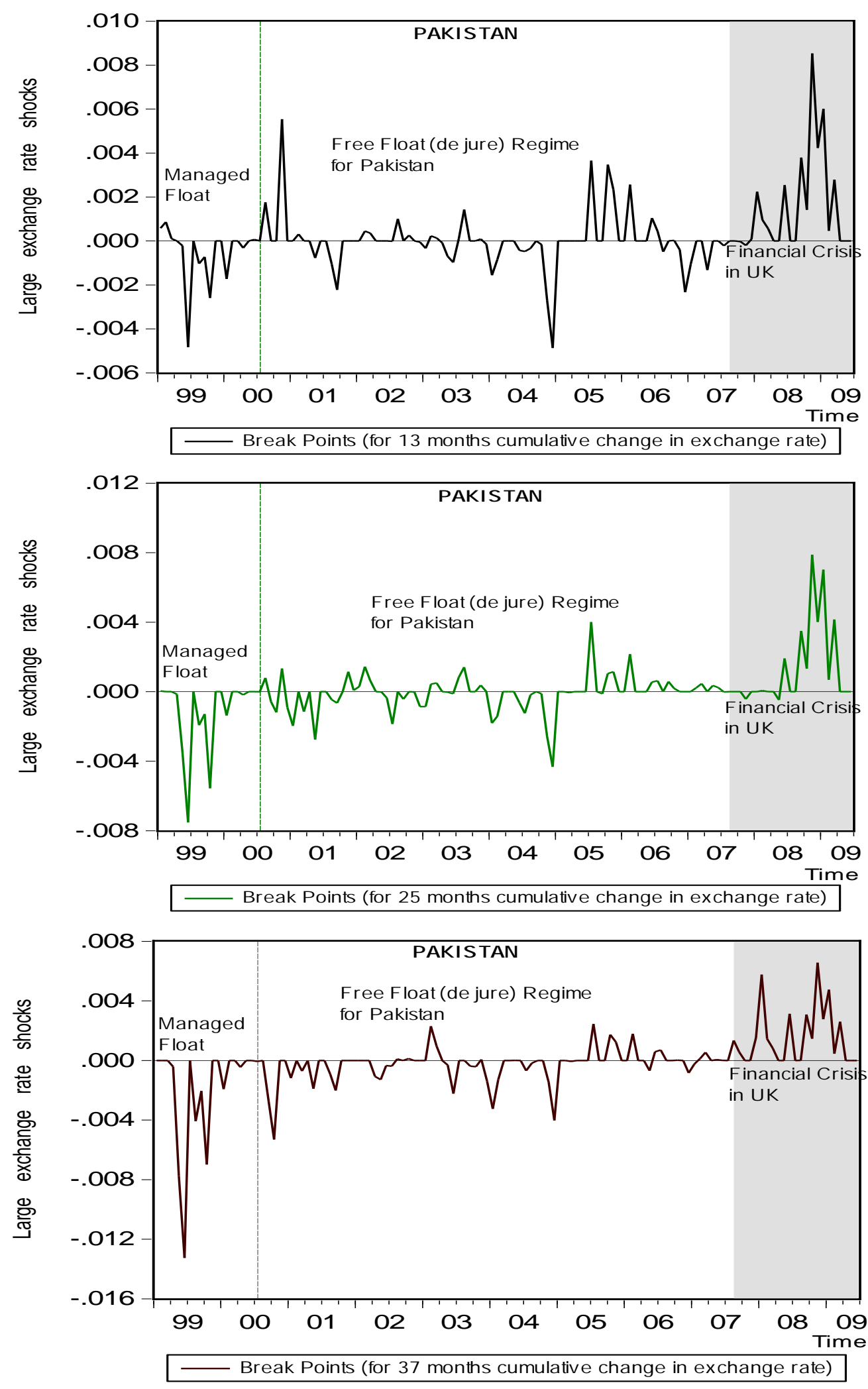
Figure 4(d): 'Large' real appreciations and depreciations of Pound Sterling against Sri Lankan Rupees
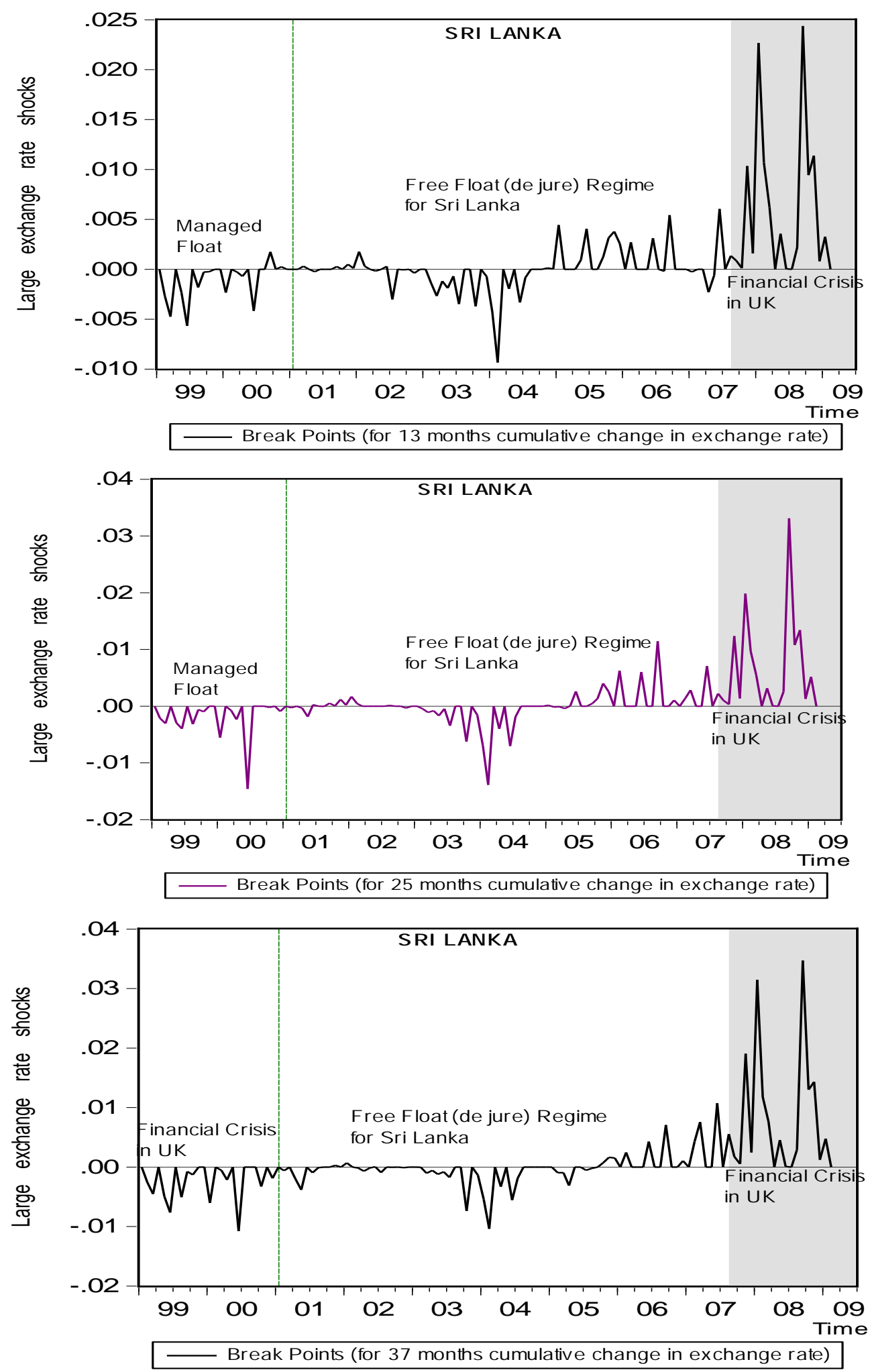
Figure 5: UK Imports from South Asia

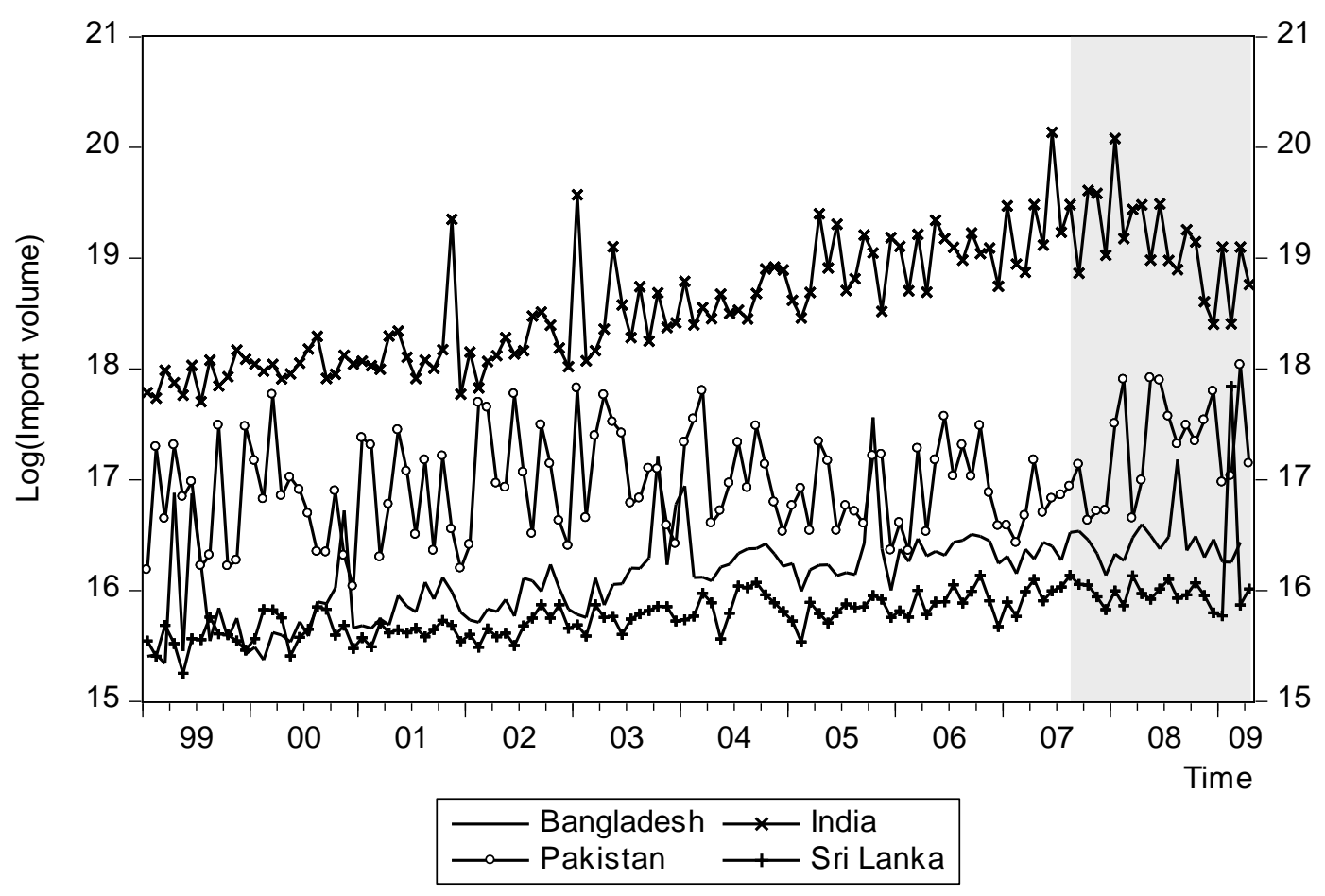




\section{Figure 6}

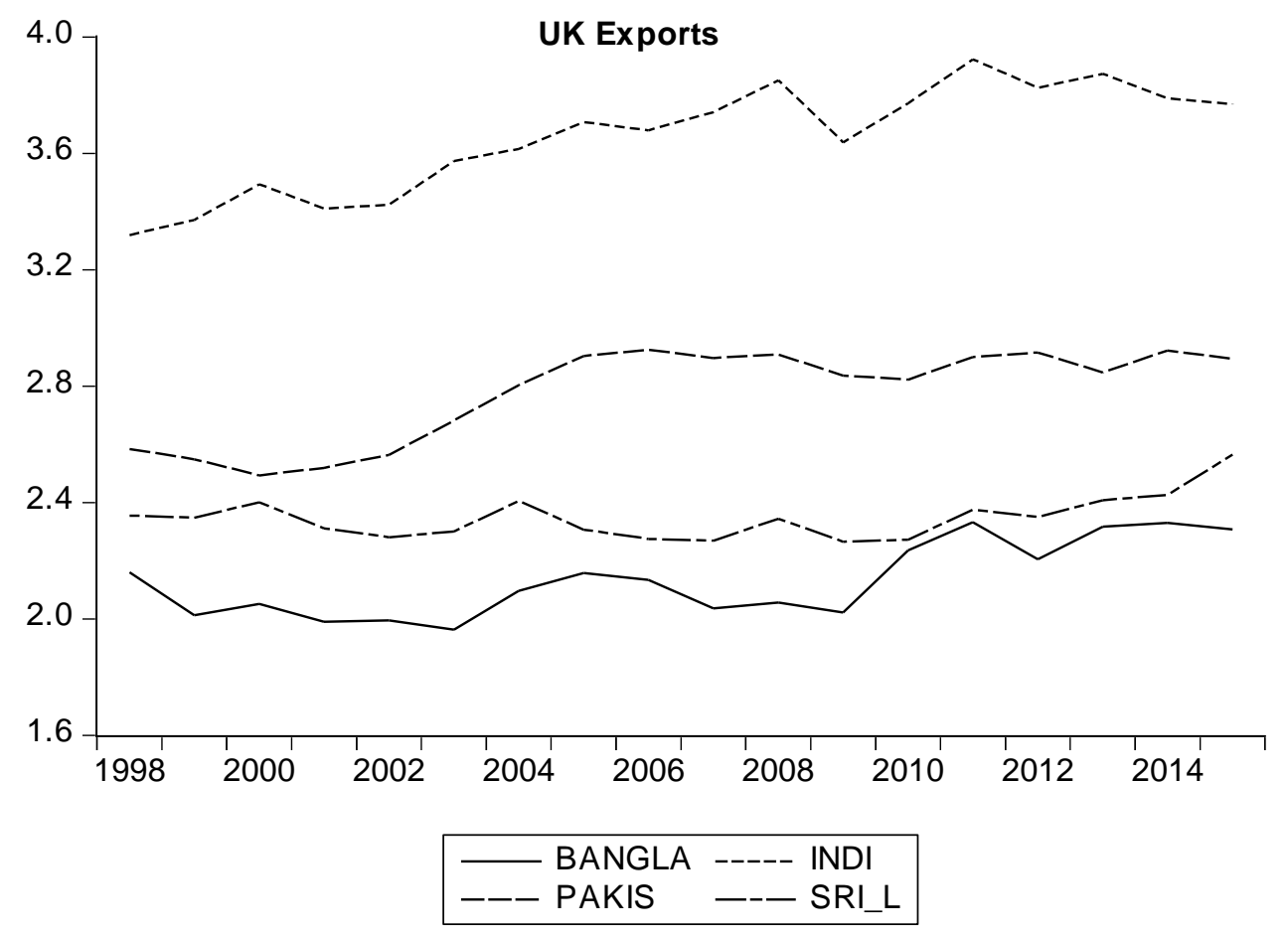




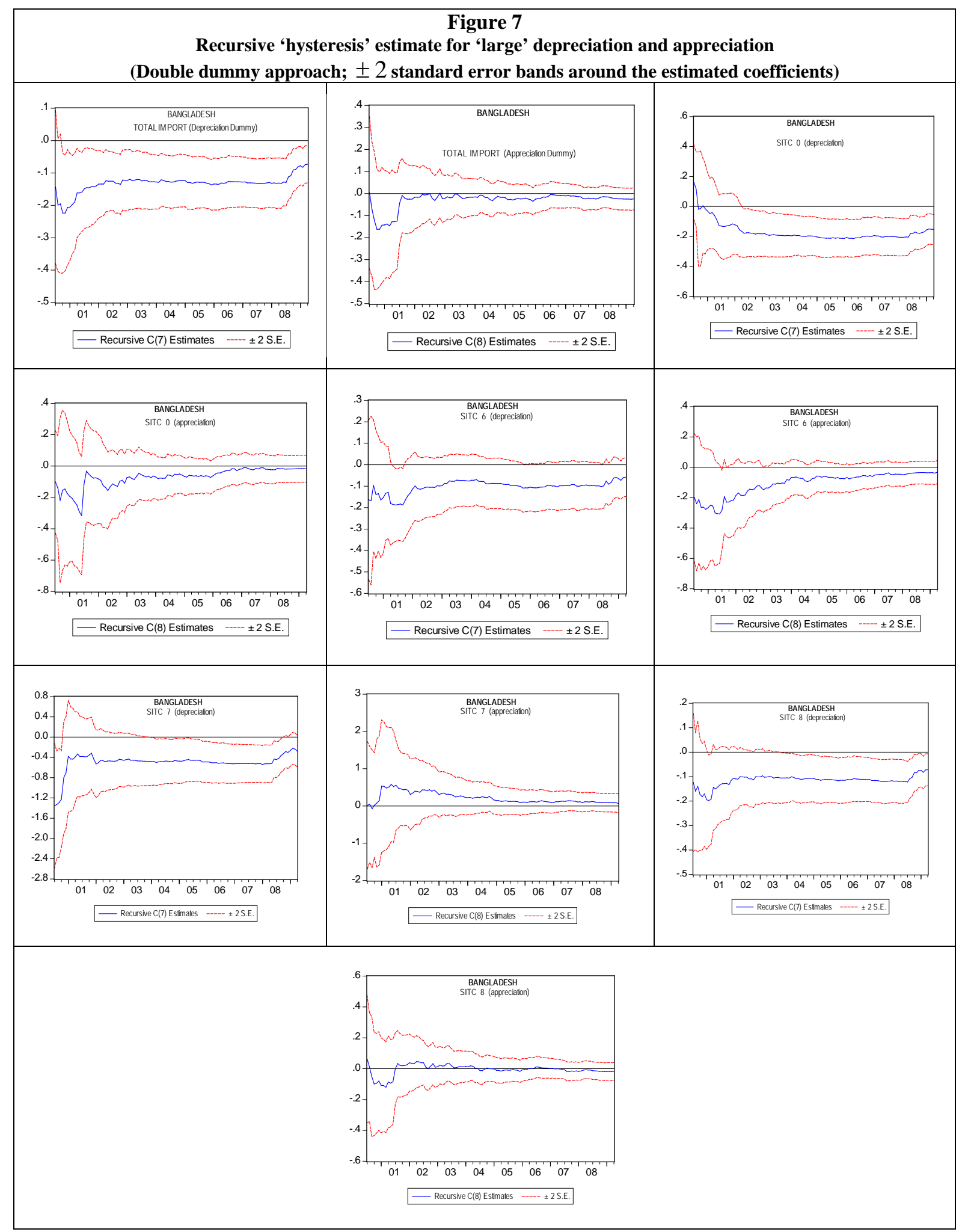


Figure 8

Recursive 'hysteresis' estimate

(single dummy approach; \pm 2 standard error bands around the estimated coefficients)
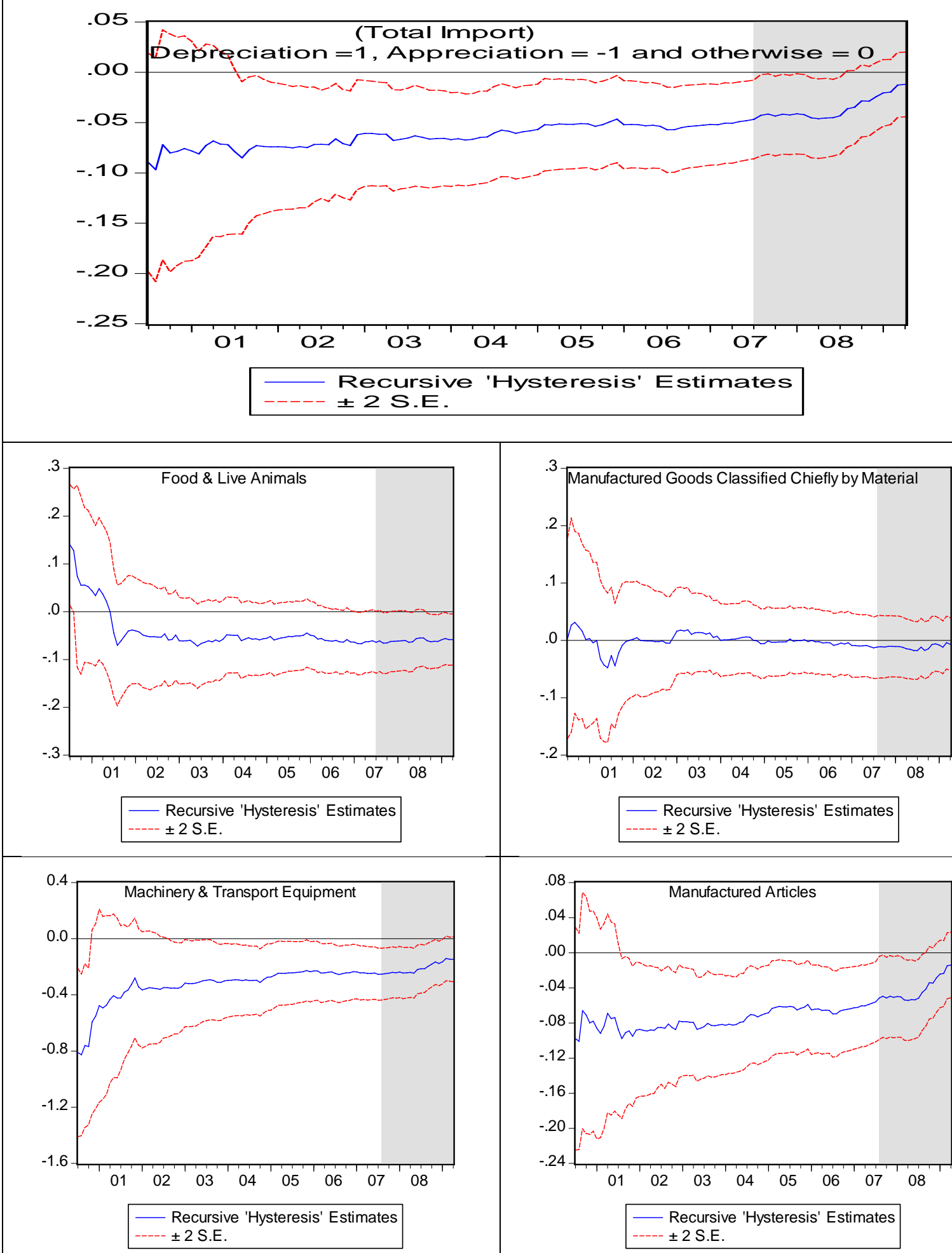
Table 1

Standard International Trade Classification (SITC)

\begin{tabular}{ccl}
\hline Sl. & SITC Code & \multicolumn{1}{c}{ SITC Title } \\
\hline 1 & Total & Total Imports \\
2 & SITC 0 & Food \& Live Animals \\
3 & SITC 1 & Beverages \& Tobacco \\
4 & SITC 2 & Crude Materials, Inedible, except fuels \\
5 & SITC 3 & Mineral Fuels, Lubricants \& Related Materials \\
6 & SITC 4 & Animal \& Vegetable Oils, Fats \& Waxes \\
7 & SITC 5 & Chemicals \& Related Products, nes \\
8 & SITC 6 & Manufactured Goods Classified Chiefly by Material \\
9 & SITC 7 & Machinery \& Transport Equipment \\
10 & SITC 8 & Miscellaneous Manufactured Articles \\
11 & SITC 9 & Commodities/Transactions not Classified Elsewhere in \\
\hline
\end{tabular}

Table 2

Classifications of exchange rate regimes of South Asian Countries

\begin{tabular}{|c|c|c|c|}
\hline Country & $\begin{array}{l}\text { De jure free floating } \\
\text { exchange rate regime } \\
\text { (Central Banks } \\
\text { announced) }\end{array}$ & $\begin{array}{l}\text { De facto (according to IMF) } \\
\text { exchange rate regime }\end{array}$ & $\begin{array}{l}\text { Monetary Policy } \\
\text { Framework }\end{array}$ \\
\hline Bangladesh & May 2003 & $\begin{array}{c}\text { Conventional fixed peg } \\
\text { arrangements }\end{array}$ & $\begin{array}{c}\text { Exchange rate } \\
\text { anchor* }\end{array}$ \\
\hline India & March 1993 & $\begin{array}{l}\text { Managed floating with no } \\
\text { predetermined path for the } \\
\text { exchange rate }\end{array}$ & Other** \\
\hline Pakistan & July 2000 & $\begin{array}{l}\text { Managed floating with no } \\
\text { predetermined path for the } \\
\text { exchange rate }\end{array}$ & Other \\
\hline Sri Lanka & January 2001 & $\begin{array}{c}\text { Conventional fixed peg } \\
\text { arrangements }\end{array}$ & $\begin{array}{c}\text { Exchange rate } \\
\text { anchor }\end{array}$ \\
\hline \multicolumn{4}{|c|}{$\begin{array}{l}\text { Source: IMF Annual Report, } 2008 \\
\text { * The monetary authority intends to buy or sell foreign exchange at given quoted rates to maintain the exchang } \\
\text { rate at its predetermined level or within a range (the exchange rate serves as the nominal anchor or intermedia } \\
\text { target of monetary policy). These regimes cover exchange rate regimes with no separate legal tender, curren } \\
\text { board arrangements, fixed pegs with or without bands, and crawling pegs with or without bands. } \\
\text { ** Includes countries that have no explicitly stated nominal anchor, but rather monitor various indicators } \\
\text { conducting monetary policy. }\end{array}$} \\
\hline
\end{tabular}


Table 3

Descriptive Statistics of UK import (volume) from South Asia

(a) UK import from Bangladesh

\begin{tabular}{|c|c|c|c|c|c|}
\hline Variable & Obs. & Mean & Std. Dev. & Min & Max \\
\hline Total & 126 & $1.12 \mathrm{e}+07$ & 5105850 & 4600356 & $4.25 \mathrm{e}+07$ \\
\hline SITC 0 & 126 & 1265868 & 319650.6 & 500938 & 1959541 \\
\hline SITC 6 & 126 & 1919286 & 487779.6 & 627168 & 3281522 \\
\hline SITC 7 & 126 & 386393.4 & 206554.1 & 421 & 954540 \\
\hline SITC 8 & 126 & 6584821 & 2818284 & 1922189 & $1.97 \mathrm{e}+07$ \\
\hline \multicolumn{6}{|c|}{ (b) UK import from India } \\
\hline Variable & Obs. & Mean & Std. Dev. & Min & Max \\
\hline Total & 126 & $1.41 \mathrm{e}+08$ & $8.80 \mathrm{e}+07$ & $4.88 e+07$ & $5.57 e+08$ \\
\hline SITC 0 & 126 & $2.36 \mathrm{e}+07$ & $1.17 e+07$ & 7012479 & $7.57 e+07$ \\
\hline SITC 1 & 126 & 641714.9 & 570063.9 & 5782 & 3342529 \\
\hline SITC 2 & 126 & $1.94 \mathrm{e}+07$ & $1.66 \mathrm{e}+07$ & 3608696 & $1.10 \mathrm{e}+08$ \\
\hline SITC 4 & 126 & 707656.4 & 330887.5 & 191125 & 2320693 \\
\hline SITC 5 & 126 & 6174818 & 2612209 & 2434346 & $1.49 \mathrm{e}+07$ \\
\hline SITC 6 & 126 & $4.14 \mathrm{e}+07$ & $1.65 \mathrm{e}+07$ & $1.69 \mathrm{e}+07$ & $9.30 \mathrm{e}+07$ \\
\hline SITC 7 & 126 & 7373937 & 3998296 & 2065151 & $1.69 \mathrm{e}+07$ \\
\hline SITC 8 & 126 & $1.07 e+07$ & 3529176 & 4807487 & $1.93 e+07$ \\
\hline \multicolumn{6}{|c|}{ (c) UK import from Pakistan } \\
\hline Variable & Obs. & Mean & Std. Dev. & Min & Max \\
\hline Total & 126 & $2.65 \mathrm{e}+07$ & $1.28 \mathrm{e}+07$ & 9192452 & $6.80 \mathrm{e}+07$ \\
\hline SITC 0 & 126 & $1.50 \mathrm{e}+07$ & $1.23 \mathrm{e}+07$ & 1547523 & $5.41 \mathrm{e}+07$ \\
\hline SITC 2 & 126 & 588340.9 & 244558.3 & 178934 & 1435989 \\
\hline SITC 5 & 126 & 671376.7 & 1046062 & 1856 & 6603781 \\
\hline SITC 6 & 126 & 6675964 & 1257442 & 3539916 & $1.12 \mathrm{e}+07$ \\
\hline SITC 7 & 126 & 109300.7 & 73275.55 & 11696 & 490172 \\
\hline SITC 8 & 126 & 3245150 & 991229 & 1487777 & 9130765 \\
\hline \multicolumn{6}{|c|}{ (d) UK import from Sri Lanka } \\
\hline Variable & Obs. & Mean & Std. Dev. & Min & Max \\
\hline Total & 126 & 7642726 & 4550513 & 4201130 & $5.62 \mathrm{e}+07$ \\
\hline SITC 0 & 126 & 1360653 & 278615.6 & 852053 & 2494370 \\
\hline SITC 1 & 126 & 43395.42 & 29531.26 & 92 & 144454 \\
\hline SITC 2 & 126 & 615014.7 & 246443.8 & 182399 & 1455778 \\
\hline SITC 5 & 126 & 123895.4 & 51919.31 & 45115 & 331287 \\
\hline SITC 6 & 126 & 1040018 & 348699.8 & 384954 & 1886205 \\
\hline SITC 7 & 126 & 403684.7 & 199037.8 & 116308 & 1218163 \\
\hline SITC 8 & 126 & 4046355 & 4554532 & 1625771 & $5.39 e+07$ \\
\hline
\end{tabular}


Table 4

ECM results for UK import from Bangladesh

(Single variable approach; $p$-value in parenthesis)

\begin{tabular}{cccccccc}
\hline SITC & $C$ & $\ln Q_{i, t-1}^{m}$ & $\Delta \ln R P_{i, t}^{m}$ & $\ln R P_{i, t-1}^{m}$ & $\Delta \ln Y_{t}$ & $\ln Y_{t-1}$ & $d_{t}$ \\
\hline Total & 6.583 & -0.137 & -1.049 & -0.095 & 0.180 & -1.009 & -0.019 \\
& $(0.000)$ & $(0.000)$ & $(0.000)$ & $(0.091)$ & $(0.377)$ & $(0.000)$ & $(0.217)$ \\
SITC 0 & 5.381 & -0.409 & 0.252 & -0.066 & 0.805 & 0.026 & $\mathbf{- 0 . 0 5 8}$ \\
& $(0.055)$ & $(0.000)$ & $(0.076)$ & $(0.525)$ & $(0.036)$ & $(0.957)$ & $\mathbf{( 0 . 0 3 4 )}$ \\
\multirow{3}{*}{ SITC 6 } & 5.917 & -0.340 & -0.937 & 0.0355 & 0.289 & -0.187 & -0.007 \\
& $(0.004)$ & $(0.000)$ & $(0.000)$ & $(0.791)$ & $(0.362)$ & $(0.646)$ & $(0.749)$ \\
SITC 7 & 12.724 & -0.684 & -1.207 & -0.802 & -0.364 & -1.506 & $\mathbf{- 0 . 1 5 7}$ \\
& $(0.039)$ & $(0.000)$ & $(0.000)$ & $(0.000)$ & $(0.723)$ & $(0.245)$ & $\mathbf{( 0 . 0 5 3 )}$ \\
SITC 8 & 8.138 & -0.149 & -1.053 & -0.130 & -0.0559 & -1.335 & -0.023 \\
& $(0.000)$ & $(0.000)$ & $(0.000)$ & $(0.031)$ & $(0.810)$ & $(0.000)$ & $(0.195)$ \\
\hline
\end{tabular}

Table 5

ECM results for UK import from India

(Single variable approach; p-value in parenthesis)

\begin{tabular}{cccccccc}
\hline SITC & Const. & $\ln Q_{i, t-1}^{m}$ & $\Delta \ln R P_{i, t}^{m}$ & $\ln R P_{i . t-1}^{m}$ & $\Delta \ln Y_{t}$ & $\ln Y_{t-1}$ & $d_{t}$ \\
\hline Total & 3.933 & -0.163 & -1.304 & -0.273 & 0.546 & -0.437 & 0.018 \\
& $(0.010)$ & $(0.002)$ & $(0.000)$ & $(0.006)$ & $(0.009)$ & $(0.088)$ & $(0.251)$ \\
SITC 0 & 3.222 & -0.387 & -1.137 & -0.428 & 0.530 & 0.269 & 0.034 \\
& $(0.131)$ & $(0.000)$ & $(0.000)$ & $(0.001)$ & $(0.107)$ & $(0.509)$ & $(0.147)$ \\
SITC 1 & 7.884 & -0.661 & -1.590 & -1.256 & 0.054 & -1.009 & -0.149 \\
& $(0.353)$ & $(0.000)$ & $(0.000)$ & $(0.001)$ & $(0.971)$ & $(0.593)$ & $(0.186)$ \\
SITC 2 & 3.769 & -0.194 & -1.243 & -0.387 & 0.156 & -0.618 & -0.010 \\
& $(0.101)$ & $(0.001)$ & $(0.000)$ & $(0.004)$ & $(0.669)$ & $(0.187)$ & $(0.719)$ \\
SITC 4 & 5.359 & -0.499 & -0.235 & 0.149 & 1.133 & 0.447 & -0.068 \\
& $(0.160)$ & $(0.000)$ & $(0.186)$ & $(0.305)$ & $(0.085)$ & $(0.605)$ & $(0.165)$ \\
SITC 5 & 4.749 & -0.216 & -1.094 & -0.263 & 0.389 & -0.503 & 0.025 \\
& $(0.051)$ & $(0.000)$ & $(0.000)$ & $(0.051)$ & $(0.268)$ & $(0.263)$ & $(0.352)$ \\
SITC 6 & 6.270 & -0.446 & -1.140 & -0.642 & 0.500 & -0.268 & -0.00004 \\
& $(0.000)$ & $(0.000)$ & $(0.000)$ & $(0.000)$ & $(0.017)$ & $(0.285)$ & $(0.998)$ \\
SITC 7 & 2.946 & -0.180 & -0.279 & -0.372 & 0.246 & -0.277 & -0.017 \\
& $(0.206)$ & $(0.001)$ & $(0.008)$ & $(0.007)$ & $(0.474)$ & $(0.537)$ & $(0.500)$ \\
SITC 8 & 3.807 & -0.121 & -1.090 & -0.228 & 0.580 & -0.526 & 0.016 \\
& $(0.001)$ & $(0.004)$ & $(0.000)$ & $(0.079)$ & $(0.000)$ & $(0.005)$ & $(0.147)$ \\
\hline
\end{tabular}


Table 6

ECM results for UK import from Pakistan

(Single variable approach; p-value in parenthesis)

\begin{tabular}{cccccccc}
\hline SITC & Const. & $\ln Q_{i, t-1}^{m}$ & $\Delta \ln R P_{i, t}^{m}$ & $\ln R P_{i . t-1}^{m}$ & $\Delta \ln Y_{t}$ & $\ln Y_{t-1}$ & $d_{t}$ \\
\hline Total & 3.504 & -0.236 & -1.000 & -0.228 & 0.739 & -0.093 & 0.008 \\
& $(0.015)$ & $(0.000)$ & $(0.000)$ & $(0.000)$ & $(0.000)$ & $(0.679)$ & $(0.538)$ \\
SITC 0 & 10.169 & -0.491 & -1.192 & -0.560 & 0.387 & -1.185 & -0.015 \\
& $(0.015)$ & $(0.000)$ & $(0.000)$ & $(0.000)$ & $(0.551)$ & $(0.151)$ & $(0.732)$ \\
SITC 2 & 10.981 & -0.554 & -0.233 & -0.123 & 0.085 & -0.919 & -0.053 \\
& $(0.003)$ & $(0.000)$ & $(0.002)$ & $(0.290)$ & $(0.882)$ & $(0.201)$ & $(0.207)$ \\
SITC 5 & 2.061 & -0.768 & -1.600 & -1.484 & 3.581 & 0.195 & $\mathbf{- 0 . 2 2 0}$ \\
& $(0.815)$ & $(0.000)$ & $(0.000)$ & $(0.000)$ & $(0.015)$ & $(0.917)$ & $\mathbf{( 0 . 0 4 2 )}$ \\
SITC 6 & 2.887 & -0.314 & -0.971 & -0.190 & 0.891 & 0.291 & $\mathbf{- 0 . 0 2 5}$ \\
& $(0.056)$ & $(0.000)$ & $(0.000)$ & $(0.028)$ & $(0.000)$ & $(0.218)$ & $\mathbf{( 0 . 0 9 2 )}$ \\
SITC 7 & -1.739 & -0.445 & -0.163 & -0.144 & 1.701 & 1.411 & 0.061 \\
& $(0.765)$ & $(0.000)$ & $(0.003)$ & $(0.057)$ & $(0.084)$ & $(0.250)$ & $(0.377)$ \\
SITC 8 & 2.868 & -0.1565 & -1.075 & -0.188 & 0.778 & -0.232 & 0.014 \\
& $(0.010)$ & $(0.001)$ & $(0.000)$ & $(0.066)$ & $(0.000)$ & $(0.237)$ & $(0.248)$ \\
\hline
\end{tabular}

Table 7

ECM results for UK import from Sri Lanka

(Single variable approach; p-value in parenthesis)

\begin{tabular}{cccccccc}
\hline SITC & Const. & $\ln Q_{i, t-1}^{m}$ & $\Delta \ln R P_{i, t}^{m}$ & $\ln R P_{i . t-1}^{m}$ & $\Delta \ln Y_{t}$ & $\ln Y_{t-1}$ & $d_{t}$ \\
\hline Total & 5.853 & -0.337 & -0.826 & -0.508 & 0.449 & -0.437 & 0.022 \\
& $(0.004)$ & $(0.000)$ & $(0.000)$ & $(0.000)$ & $(0.068)$ & $(0.192)$ & $(0.241)$ \\
SITC 0 & 8.424 & -0.519 & -0.684 & 0.061 & 0.518 & -0.181 & -0.029 \\
& $(0.000)$ & $(0.000)$ & $(0.000)$ & $(0.363)$ & $(0.065)$ & $(0.623)$ & $(0.122)$ \\
SITC 1 & 2.554 & -0.965 & -0.401 & -0.596 & 2.518 & 1.353 & -0.084 \\
& $(0.759)$ & $(0.000)$ & $(0.000)$ & $(0.000)$ & $(0.072)$ & $(0.452)$ & $(0.452)$ \\
SITC 2 & 3.151 & -0.048 & -0.754 & 0.018 & 0.546 & -0.542 & $\mathbf{- 0 . 0 7 5}$ \\
& $(0.359)$ & $(0.535)$ & $(0.000)$ & $(0.840)$ & $(0.341)$ & $(0.465)$ & $\mathbf{( 0 . 0 8 9 )}$ \\
SITC 5 & 4.711 & -0.882 & -0.662 & -0.647 & 0.332 & 0.604 & $\mathbf{- 0 . 1 1 2}$ \\
& $(0.194)$ & $(0.000)$ & $(0.000)$ & $(0.000)$ & $(0.567)$ & $(0.427)$ & $\mathbf{( 0 . 0 0 9 )}$ \\
SITC 6 & 2.785 & -0.499 & -0.735 & -0.644 & 1.199 & 0.322 & 0.034 \\
& $(0.150)$ & $(0.000)$ & $(0.000)$ & $(0.000)$ & $(0.000)$ & $(0.415)$ & $(0.163)$ \\
SITC 7 & 1.601 & -0.482 & -0.490 & -0.241 & 1.925 & 0.831 & 0.047 \\
& $(0.638)$ & $(0.000)$ & $(0.000)$ & $(0.013)$ & $(0.001)$ & $(0.259)$ & $(0.295)$ \\
SITC 8 & 4.428 & -0.247 & -0.906 & -0.530 & 0.482 & -0.489 & -0.001 \\
& $(0.060)$ & $(0.001)$ & $(0.000)$ & $(0.000)$ & $(0.112)$ & $(0.225)$ & $(0.960)$ \\
\hline
\end{tabular}




\section{Table 8}

ECM results for UK imports from Bangladesh

(Double variable approach; $p$-value in parenthesis)

\begin{tabular}{lllllllll}
\hline & $C$ & $\ln Q_{i, t-1}^{m}$ & $\Delta \ln R P_{i, t}^{m}$ & $\ln R P_{i . t-1}^{m}$ & $\Delta \ln Y_{t}$ & $\ln Y_{t-1}$ & $d_{t}^{D}$ & $d_{t}^{A}$ \\
\hline Total & 6.696 & -0.1385 & -1.063 & -0.109 & 0.204 & -1.032 & $\mathbf{- 0 . 0 7 3}$ & -0.025 \\
& $(0.000)$ & $(0.000)$ & $(0.000)$ & $(0.051)$ & $(0.312)$ & $(0.000)$ & $\mathbf{( 0 . 0 1 2 )}$ & $(0.323)$ \\
SITC 0 & 6.0185 & -0.425 & 0.246 & -0.046 & 0.826 & -0.039 & $\mathbf{- 0 . 1 5 3}$ & -0.017 \\
& $(0.030)$ & $(0.000)$ & $(0.079)$ & $(0.652)$ & $(0.029)$ & $(0.934)$ & $\mathbf{( 0 . 0 0 3 )}$ & $(0.691)$ \\
SITC 6 & 6.123 & -0.352 & -0.915 & 0.029 & 0.311 & -0.196 & -0.059 & -0.033 \\
& $(0.003)$ & $(0.000)$ & $(0.000)$ & $(0.827)$ & $(0.326)$ & $(0.630)$ & $(0.201)$ & $(0.398)$ \\
SITC 7 & 13.105 & -0.674 & -1.191 & -0.755 & -0.308 & -1.568 & $\mathbf{- 0 . 2 7 5}$ & 0.070 \\
& $(0.034)$ & $(0.000)$ & $(0.000)$ & $(0.000)$ & $(0.765)$ & $(0.227)$ & $\mathbf{( 0 . 0 8 2 )}$ & $(0.583)$ \\
SITC 8 & 8.215 & -0.151 & -1.061 & 0.140 & -0.031 & -1.346 & $\mathbf{- 0 . 0 7 2}$ & -0.017 \\
& $(0.000)$ & $(0.000)$ & $(0.000)$ & $(0.020)$ & $(0.893)$ & $(0.000)$ & $\mathbf{( 0 . 0 3 0 )}$ & $(0.547)$ \\
\hline
\end{tabular}

Results of the Delta Method for the Long-run UK import from Bangladesh

(Double variable approach; standard error in parenthesis)

\begin{tabular}{cccccc}
\hline SITC & $C$ & $\ln R P_{t}^{m}$ & $\ln Y_{t}$ & $d_{t}^{D}$ & $d_{t}^{A}$ \\
\hline Total & $48.35^{* * *}$ & $-0.79^{* *}$ & $-7.45^{* *}$ & $\mathbf{- 0 . 5 3 * *}$ & -0.18 \\
& $(10.71)$ & $(0.36)$ & $(2.34)$ & $\mathbf{( 0 . 2 3 )}$ & $(0.19)$ \\
SITC 0 & $14.17^{* *}$ & -0.11 & -0.09 & $\mathbf{- 0 . 3 6 * *}$ & -0.04 \\
& $(5.39)$ & $(0.24)$ & $(1.09)$ & $\mathbf{( 0 . 1 2 )}$ & $(0.10)$ \\
SITC 6 & $17.42^{* *}$ & 0.08 & -0.56 & -0.17 & -0.09 \\
& $(5.11)$ & $(0.38)$ & $(1.16)$ & $(0.13)$ & $(0.11)$ \\
SITC 7 & $19.44^{* *}$ & $-1.12^{* *}$ & $-2.32^{*}$ & $\mathbf{- 0 . 4 1 *}$ & 0.10 \\
& $(9.17)$ & $(0.22)$ & $(1.94)$ & $\mathbf{( 0 . 2 4 )}$ & $(0.19)$ \\
SITC 8 & $54.33^{* *}$ & $-0.93^{* *}$ & $-8.90^{* *}$ & $\mathbf{- 0 . 4 8 * *}$ & -0.11 \\
& $(11.69)$ & $(0.34)$ & $(2.53)$ & $\mathbf{( 0 . 2 3 )}$ & $(0.20)$ \\
\hline
\end{tabular}

Note: Delta method computed using analytic derivatives. $* *$ and $*$ reject the restrictions $\left(\mathrm{H}_{0}\right.$ : parameter is equal to zero) at $5 \%$ and $10 \%$ level of significance. 
Table 9

ECM results for UK import from India

(Double variable approach; $p$-value in parenthesis)

\begin{tabular}{lllllllll}
\hline SITC & $C$ & $\ln Q_{i, t-1}^{m}$ & $\Delta \ln R P_{i, t}^{m}$ & $\ln R P_{i . t-1}^{m}$ & $\Delta \ln Y_{t}$ & $\ln Y_{t-1}$ & $d_{t}^{D}$ & $d_{t}^{A}$ \\
\hline Total & 3.827 & -0.164 & -1.314 & -0.281 & 0.567 & -0.410 & -0.012 & $\mathbf{- 0 . 0 5 6}$ \\
& $(0.012)$ & $(0.002)$ & $(0.000)$ & $(0.005)$ & $(0.007)$ & $(0.108)$ & $(0.626)$ & $\mathbf{( 0 . 0 5 6 )}$ \\
SITC 0 & 2.998 & -0.392 & -1.155 & -0.445 & 0.581 & 0.326 & -0.031 & $\mathbf{- 0 . 1 3 3}$ \\
& $(0.150)$ & $(0.000)$ & $(0.000)$ & $(0.000)$ & $(0.072)$ & $(0.413)$ & $(0.442)$ & $\mathbf{( 0 . 0 0 4 )}$ \\
SITC 1 & 7.535 & -0.659 & -1.576 & -1.279 & 0.140 & -0.942 & -0.287 & -0.018 \\
& $(0.375)$ & $(0.000)$ & $(0.000)$ & $(0.001)$ & $(0.924)$ & $(0.618)$ & $(0.124)$ & $(0.931)$ \\
SITC 2 & 3.785 & -0.201 & -1.241 & -0.405 & 0.115 & -0.619 & -0.022 & -0.045 \\
& $(0.099)$ & $(0.001)$ & $(0.000)$ & $(0.004)$ & $(0.756)$ & $(0.185)$ & $(0.622)$ & $(0.388)$ \\
SITC 4 & 4.503 & -0.483 & -0.265 & 0.117 & 1.1665 & 0.562 & -0.114 & -0.095 \\
& $(0.238)$ & $(0.000)$ & $(0.136)$ & $(0.426)$ & $(0.079)$ & $(0.518)$ & $(0.165)$ & $(0.302)$ \\
SITC 5 & 4.849 & -0.218 & -1.090 & -0.259 & 0.377 & -0.519 & 0.040 & -0.007 \\
& $(0.048)$ & $(0.000)$ & $(0.000)$ & $(0.056)$ & $(0.286)$ & $(0.251)$ & $(0.363)$ & $(0.881)$ \\
SITC 6 & 6.289 & -0.449 & -1.142 & -0.647 & 0.497 & -0.268 & -0.001 & -0.006 \\
& $(0.000)$ & $(0.000)$ & $(0.000)$ & $(0.000)$ & $(0.018)$ & $(0.288)$ & $(0.983)$ & $(0.841)$ \\
SITC 7 & 3.141 & -0.193 & -0.302 & -0.408 & 0.177 & -0.294 & -0.054 & -0.058 \\
& $(0.178)$ & $(0.001)$ & $(0.005)$ & $(0.004)$ & $(0.608)$ & $(0.510)$ & $(0.195)$ & $(0.232)$ \\
SITC 8 & 3.911 & -0.126 & -1.105 & -0.268 & 0.558 & -0.551 & -0.004 & $\mathbf{- 0 . 0 4 7}$ \\
& $(0.000)$ & $(0.003)$ & $(0.000)$ & $(0.048)$ & $(0.000)$ & $(0.003)$ & $(0.830)$ & $\mathbf{( 0 . 0 3 4 )}$ \\
\hline
\end{tabular}

Results of the Delta Method for the Long-run UK import from India (Double variable approach; standard error in parenthesis)

\begin{tabular}{cccccc}
\hline SITC & $C$ & $\ln R P_{t}^{m}$ & $\ln Y_{t}$ & $d_{t}^{D}$ & $d_{t}^{A}$ \\
\hline Total & $23.29^{* *}$ & $-1.71^{* *}$ & $-2.49^{*}$ & -0.07 & $\mathbf{- 0 . 3 4 *}$ \\
& $(6.73)$ & $(0.25)$ & $(1.44)$ & $(0.16)$ & $\mathbf{( 0 . 1 8 7 )}$ \\
SITC 0 & $7.65^{* *}$ & $-1.13^{* *}$ & 0.83 & -0.08 & $\mathbf{- 0 . 3 4 * *}$ \\
& $(4.75)$ & $(0.17)$ & $(1.03)$ & $(0.105)$ & $\mathbf{( 0 . 1 4 )}$ \\
SITC 1 & 11.43 & $-1.94^{* *}$ & -1.43 & -0.44 & -0.03 \\
& $(12.92)$ & $(0.48)$ & $(2.87)$ & $(0.28)$ & $(0.32)$ \\
SITC 2 & $18.87^{* *}$ & $-2.02^{* *}$ & -3.08 & -0.11 & -0.23 \\
\multirow{2}{*}{ SITC 4 } & $(10.67)$ & $(0.32)$ & $(2.23)$ & $(0.22)$ & $(0.26)$ \\
& $9.32^{* *}$ & 0.24 & 1.16 & -0.24 & -0.20 \\
SITC 5 & $(7.77)$ & $(0.30)$ & $(1.77)$ & $(0.18)$ & $(0.19)$ \\
& $22.28^{* *}$ & $-1.19^{* *}$ & -2.38 & 0.18 & -0.03 \\
SITC 6 & $(9.36)$ & $(0.51)$ & $(1.96)$ & $(0.20)$ & $(0.22)$ \\
& $14.01^{* *}$ & $-1.44^{* *}$ & -0.60 & -0.001 & -0.014 \\
SITC 7 & $(2.65)$ & $(0.11)$ & $(0.56)$ & $(0.058)$ & $(0.07)$ \\
& $16.29 * *$ & $-2.12^{* *}$ & -1.52 & -0.28 & -0.30 \\
SITC 8 & $(10.23)$ & $(0.44)$ & $(2.18)$ & $(0.23)$ & $(0.25)$ \\
& $30.97^{* *}$ & $-2.12^{* *}$ & $-4.36 * *$ & -0.03 & $\mathbf{- 0 . 3 7 *}$ \\
& $(8.32)$ & $(0.64)$ & $(1.69)$ & $(0.15)$ & $\mathbf{( 0 . 1 9 )}$ \\
\hline
\end{tabular}


Table 10

ECM results for UK import from Pakistan

(Double variable approach; $p$-value in parenthesis)

\begin{tabular}{llllllllc}
\hline & $C$ & $\ln Q_{i, t-1}^{m}$ & $\Delta \ln R P_{i, t}^{m}$ & $\ln R P_{i . t-1}^{m}$ & $\Delta \ln Y_{t}$ & $\ln Y_{t-1}$ & $d_{t}^{D}$ & $d_{t}^{A}$ \\
\hline Total & 3.406 & -0.230 & -0.995 & -0.215 & 0.752 & -0.083 & 0.026 & 0.009 \\
& $(0.019)$ & $(0.000)$ & $(0.000)$ & $(0.001)$ & $(0.000)$ & $(0.709)$ & $(0.287)$ & $(0.712)$ \\
SITC 0 & 8.304 & -0.491 & -1.196 & -0.552 & 0.587 & -0.785 & 0.129 & 0.103 \\
& $(0.051)$ & $(0.000)$ & $(0.000)$ & $(0.000)$ & $(0.371)$ & $(0.352)$ & $(0.147)$ & $(0.205)$ \\
SITC 2 & 10.694 & -0.556 & -0.229 & -0.122 & 0.117 & -0.849 & -0.034 & 0.036 \\
& $(0.004)$ & $(0.000)$ & $(0.003)$ & $(0.302)$ & $(0.840)$ & $(0.246)$ & $(0.656)$ & $(0.628)$ \\
SITC 5 & 3.081 & -0.748 & -1.619 & -1.469 & 3.354 & -0.0332 & $\mathbf{- 0 . 3 5 9}$ & -0.175 \\
& $(0.733)$ & $(0.000)$ & $(0.000)$ & $(0.000)$ & $(0.026)$ & $(0.986)$ & $\mathbf{( 0 . 0 9 9 7 )}$ & $(0.357)$ \\
SITC 6 & 2.827 & -0.311 & -0.980 & -0.167 & 0.896 & 0.313 & -0.023 & -0.012 \\
& $(0.066)$ & $(0.000)$ & $(0.000)$ & $(0.055)$ & $(0.000)$ & $(0.195)$ & $(0.386)$ & $(0.632)$ \\
SITC 7 & -1.806 & -0.434 & -0.156 & -0.136 & 1.712 & 1.397 & 0.097 & -0.006 \\
& $(0.759)$ & $(0.000)$ & $(0.005)$ & $(0.076)$ & $(0.085)$ & $(0.258)$ & $(0.445)$ & $(0.961)$ \\
SITC 8 & 2.851 & -0.157 & -1.075 & -0.190 & 0.779 & -0.228 & 0.019 & -0.009 \\
& $(0.011)$ & $(0.001)$ & $(0.000)$ & $(0.065)$ & $(0.000)$ & $(0.248)$ & $(0.413)$ & $(0.653)$ \\
\hline
\end{tabular}

Results of the Delta Method for the Long-run UK import from Pakistan

(Double variable approach; standard error in parenthesis)

\begin{tabular}{cccccc}
\hline SITC & $C$ & $\ln R P_{t}^{m}$ & $\ln Y_{t}$ & $d_{t}^{D}$ & $d_{t}^{A}$ \\
\hline Total & $14.81^{* *}$ & $-0.93^{* *}$ & -0.36 & 0.114 & 0.038 \\
& $(4.52)$ & $(0.13)$ & $(0.95)$ & $(0.111)$ & $(0.103)$ \\
SITC 0 & $16.91^{* *}$ & $-1.12^{* *}$ & -1.60 & 0.26 & 0.21 \\
& $(7.72)$ & $(0.13)$ & $(1.65)$ & $(0.19)$ & $(0.17)$ \\
SITC 2 & $19.22^{* *}$ & -0.22 & -1.53 & -0.06 & 0.06 \\
& $(6.11)$ & $(0.21)$ & $(1.30)$ & $(0.14)$ & $(0.13)$ \\
SITC 5 & 4.12 & $-1.96^{* *}$ & -0.04 & $\mathbf{- 0 . 4 8 *}$ & -0.23 \\
& $(12.09)$ & $(0.15)$ & $(2.58)$ & $\mathbf{( 0 . 2 9 )}$ & $(0.26)$ \\
SITC 6 & $9.11^{* *}$ & $-0.54^{* *}$ & 1.01 & -0.07 & -0.04 \\
& $(4.01)$ & $(0.25)$ & $(0.80)$ & $(0.08)$ & $(0.08)$ \\
SITC 7 & -4.16 & $-0.313^{*}$ & 3.22 & 0.225 & -0.014 \\
& $(13.79)$ & $(0.168)$ & $(2.97)$ & $(0.299)$ & $(0.279)$ \\
SITC 8 & $18.15^{* *}$ & $-1.21^{* *}$ & -1.45 & 0.12 & -0.06 \\
& $(6.39)$ & $(0.47)$ & $(1.28)$ & $(0.15)$ & $(0.14)$ \\
\hline
\end{tabular}




\section{Table 11}

ECM results UK import from Sri Lanka.

(Double variable approach; $p$-value in parenthesis)

\begin{tabular}{lllllllll}
\hline SITC & $C$ & $\ln Q_{i, t-1}^{m}$ & $\Delta \ln R P_{i, t}^{m}$ & $\ln R P_{i . t-1}^{m}$ & $\Delta \ln Y_{t}$ & $\ln Y_{t-1}$ & $d_{t}^{D}$ & $d_{t}^{A}$ \\
\hline Total & 5.990 & -0.338 & -0.821 & -0.503 & 0.440 & -0.459 & 0.008 & -0.034 \\
& $(0.004)$ & $(0.000)$ & $(0.000)$ & $(0.000)$ & $(0.077)$ & $(0.172)$ & $(0.795)$ & $(0.301)$ \\
SITC 0 & 8.537 & -0.519 & -0.692 & 0.034 & 0.475 & -0.231 & -0.015 & -0.005 \\
& $(0.000)$ & $(0.000)$ & $(0.000)$ & $(0.645)$ & $(0.094)$ & $(0.536)$ & $(0.686)$ & $(0.898)$ \\
SITC 1 & 2.869 & -0.965 & -0.394 & -0.572 & 2.455 & 1.311 & -0.127 & -0.069 \\
& $(0.733)$ & $(0.001)$ & $(0.001)$ & $(0.000)$ & $(0.081)$ & $(0.469)$ & $(0.481)$ & $(0.706)$ \\
SITC 2 & 3.766 & -0.048 & -0.748 & 0.032 & 0.486 & -0.649 & $\mathbf{- 0 . 1 4 5}$ & -0.028 \\
& $(0.286)$ & $(0.534)$ & $(0.000)$ & $(0.750)$ & $(0.402)$ & $(0.389)$ & $\mathbf{( 0 . 1 0 9 7 )}$ & $(0.697)$ \\
SITC 5 & 3.436 & -0.872 & -0.651 & -0.676 & 0.462 & 0.846 & $-\mathbf{0 . 2 5 8}$ & -0.053 \\
& $(0.324)$ & $(0.000)$ & $(0.000)$ & $(0.000)$ & $(0.415)$ & $(0.249)$ & $\mathbf{( 0 . 0 0 1 )}$ & $(0.483)$ \\
SITC 6 & 2.897 & -0.519 & -0.753 & -0.671 & 1.191 & 0.336 & 0.008 & $-\mathbf{0 . 0 7 4}$ \\
& $(0.133)$ & $(0.000)$ & $(0.000)$ & $(0.000)$ & $(0.000)$ & $(0.392)$ & $(0.836)$ & $\mathbf{( 0 . 0 7 6 )}$ \\
SITC 7 & 1.692 & -0.474 & -0.484 & -0.229 & 1.922 & 0.804 & -0.007 & -0.110 \\
& $(0.619)$ & $(0.000)$ & $(0.000)$ & $(0.019)$ & $(0.001)$ & $(0.273)$ & $(0.931)$ & $(0.154)$ \\
SITC 8 & 6.073 & -0.498 & -0.938 & -0.755 & 0.534 & -0.081 & 0.011 & -0.041 \\
& $(0.006)$ & $(0.000)$ & $(0.000)$ & $(0.000)$ & $(0.072)$ & $(0.846)$ & $(0.758)$ & $(0.289)$ \\
\hline
\end{tabular}

Results of the Delta Method for the Long-run UK import from Sri Lanka

(Double variable approach; standard error in parenthesis)

\begin{tabular}{cccccc}
\hline SITC & $C$ & $\ln R P_{t}^{m}$ & $\ln Y_{t}$ & $d_{t}^{D}$ & $d_{t}^{A}$ \\
\hline Total & $17.73^{* *}$ & $-1.49^{* *}$ & -1.35 & 0.02 & -0.10 \\
& $(5.00)$ & $(0.44)$ & $(1.04)$ & $(0.09)$ & $(0.09)$ \\
SITC 0 & $16.45^{* *}$ & 0.07 & -0.44 & -0.03 & -0.01 \\
& $(3.16)$ & $(0.14)$ & $(0.71)$ & $(0.07)$ & $(0.07)$ \\
SITC 1 & 2.97 & $-0.59^{* *}$ & 1.36 & -0.13 & -0.07 \\
& $(8.68)$ & $(0.09)$ & $(1.87)$ & $(0.18)$ & $(0.19)$ \\
SITC 2 & 66.51 & -0.15 & -11.88 & -1.97 & -0.98 \\
& $(113.44)$ & $(1.85)$ & $(24.39)$ & $(3.45)$ & $(2.20)$ \\
SITC 5 & 3.94 & $-0.78^{* *}$ & 0.97 & $\mathbf{- 0 . 3 0 * *}$ & -0.06 \\
& $(3.96)$ & $(0.15)$ & $(0.83)$ & $\mathbf{( 0 . 0 9 )}$ & $(0.09)$ \\
SITC 6 & $5.59^{* *}$ & $-1.29^{* *}$ & 0.65 & 0.02 & $\mathbf{- 0 . 1 4 *}$ \\
& $(3.59)$ & $(0.17)$ & $(0.74)$ & $(0.08)$ & $\mathbf{( 0 . 0 8 )}$ \\
SITC 7 & 3.57 & $-0.48^{* *}$ & 1.70 & -0.01 & -0.23 \\
& $(7.10)$ & $(0.17)$ & $(1.53)$ & $(0.16)$ & $(0.17)$ \\
SITC 8 & $12.18^{* *}$ & $-1.515^{* *}$ & -0.16 & 0.02 & -0.08 \\
& $(4.05)$ & $(0.263)$ & $(0.83)$ & $(0.07)$ & $(0.07)$ \\
\hline
\end{tabular}

